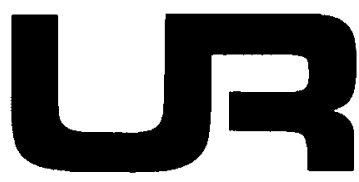

UNITED STATES

URANIUM REGISTRY

\title{
Radiological Health Aspects of Uranium Milling
}

D.R. Fisher

G.A. Stoetzel

May 1983

Prepared by

Pacific Northwest Laboratory

for the Hanford Environmental Health Foundation

and the U.S. Department of Energy

under Contract DE-AC06-76RLO 1830 


\title{
DISCLAIMER
}

This report was prepared as an account of work sponsored by an agency of the United States Government. Neither the United States Government nor any agency thereof, nor any of their employees, makes any warranty, express or implied, or assumes any legal liability or responsibility for the accuracy, completeness, or usefulness of any information, apparatus, product, or process disclosed, or represents that its use would not infringe privately owned rights. Reference herein to any specific commercial product, process, or service by trade name, trademark, manufacturer, or otherwise, does not necessarily constitute or imply its endorsement, recommendation, or favoring by the United States Government or any agency thereof. The views and opinions of authors expressed herein do not necessarily state or reflect those of the United States Government or any agency thereof.

\author{
PACIFIC NORTHWEST LABORATORY \\ operated by \\ BATTELLE \\ for the \\ UNITED STATES DEPARTMENT OF ENERGY \\ under Contract DE-AC06-76RLO 1830
}

\begin{tabular}{|c|c|}
\hline \multirow{2}{*}{\multicolumn{2}{|c|}{ Printed in the United States of America }} \\
\hline & \\
\hline \multicolumn{2}{|c|}{$\begin{array}{l}\text { Available from } \\
\text { National Tochnical Information Service }\end{array}$} \\
\hline \multirow{4}{*}{\multicolumn{2}{|c|}{$\begin{array}{c}\text { National Technical Information Service } \\
\text { Unired Srates Department of Commerce } \\
5285 \text { Port Royal Road } \\
\text { Springfield, Virginia } 22761\end{array}$}} \\
\hline & \\
\hline & \\
\hline & \\
\hline \multirow{2}{*}{\multicolumn{2}{|c|}{$\begin{array}{l}\text { Vils Price Codes } \\
\text { Microfiche A01 }\end{array}$}} \\
\hline & \\
\hline \multicolumn{2}{|c|}{ Printed Copy } \\
\hline & Price \\
\hline Pages & Codes \\
\hline $007-025$ & $\mathrm{~A} 02$ \\
\hline $026-050$ & $\mathrm{~A} 03$ \\
\hline $051-075$ & $\mathrm{~A} 04$ \\
\hline $076-100$ & A05 \\
\hline $101-125$ & $A 06$ \\
\hline $126-150$ & A07 \\
\hline $151-175$ & $A 08$ \\
\hline $176-200$ & A09 \\
\hline $201-225$ & A010 \\
\hline $226-250$ & A011 \\
\hline $251-275$ & A012 \\
\hline $276-300$ & $\mathrm{~A} 013$ \\
\hline
\end{tabular}




\title{
Radiological Health Aspects of Uranium Milling
}

\author{
D.R. Fisher \\ G.A. Stoetzel
}

Prepared by Pacific Northwest Laboratory for Hanford Environmental Health Foundation and the U.S. Department of Energy under

Contract DE-AC06-76RLO 1830 


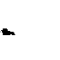




\section{PREFACE}

This report is the fourth in a series of reports written in support of the United States Uranium Registry Program. The first report (PNL-3341 USUR-01) entitled Occupational Exposures to Uranium: Processes, Hazards and Regulations - A Field Study of the Commercial Fuel Cycle was published in April 1981. The second report (USUR-02), entitled An Appraisal of Selected Epidemiologic Issues From Studies of Lung Cancer Among Uranium and Hard Rock Miners was published in April 1982. The third report in this series (PNL-4438 USUR-03), Radiological Health Aspects of Commercial Uranium Conversion, Enrichment, and Fuel Fabrication was published in November 1982. The present report completes the review of radiological health practices in the commercial uranium fuel cycle. 


\section{CONTENTS}

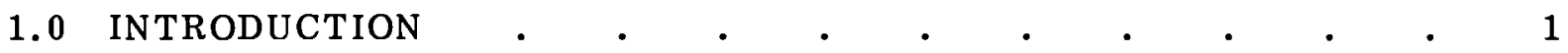

1.1 URANIUM MILLS AND NATURAL RADIOACTIVITY . . . 2

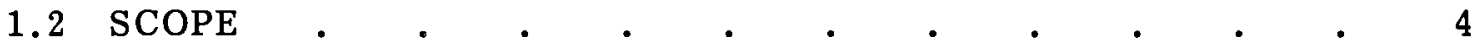

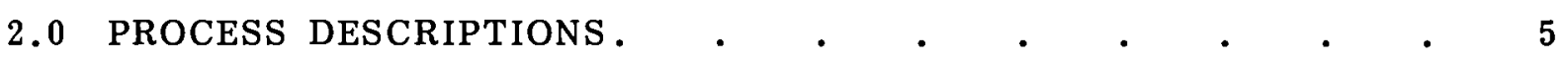

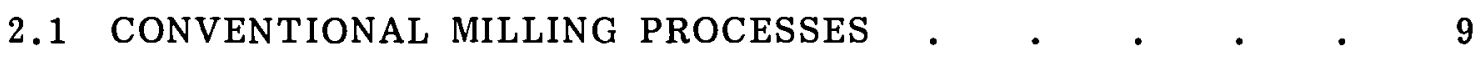

2.1.1 Ore Handling and Preparation $\quad . \quad$. $\quad . \quad . \quad$. $\quad 9$

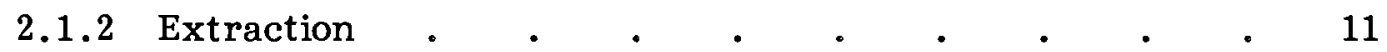

2.1.3 Concentration and Purification . . . . . . 12

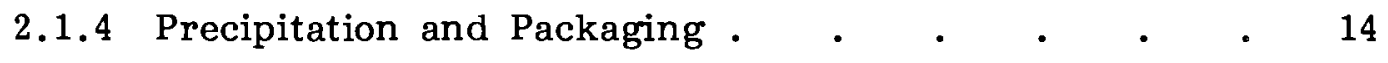

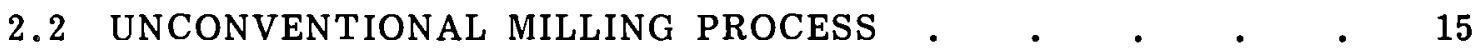

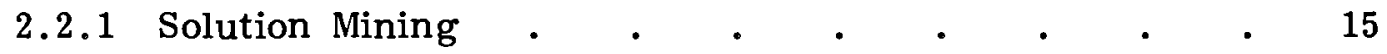

2.2.2 Uranium Recovery Operations . . . . . . 16

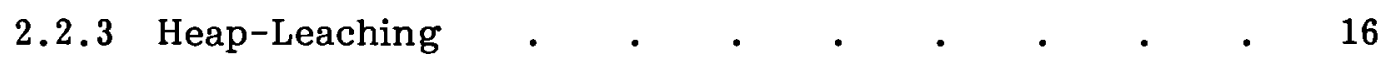

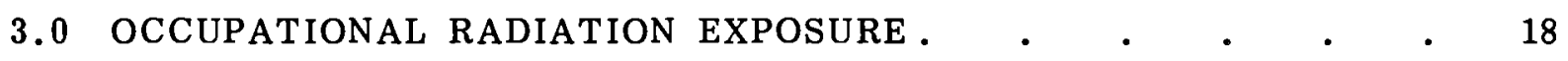

3.1 ORE HANDLING AND PREPARATION $\quad . \quad$. $\quad . \quad$ • $\quad$ - 19

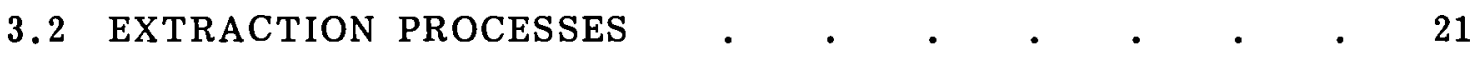

3.3 CONCENTRATION AND PURIFICATION • • • • • $\quad 21$

3.4 PRECIPITATION AND PACKAGING . $\quad$ • $\quad$ • $\quad$ • $\quad 21$

4.0 METHODS FOR RADIOLOGICAL PROTECTION . • . . . • $\quad 23$

4.1 ORGANIZATION RESPONSIBILITIES $\quad$ • $\quad$ • $\quad$ • $\quad$ • $\quad$ • 24

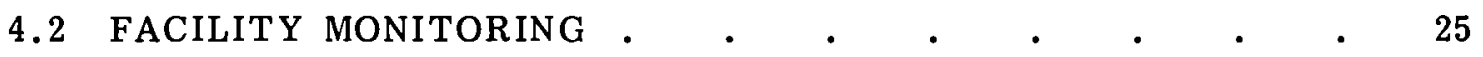

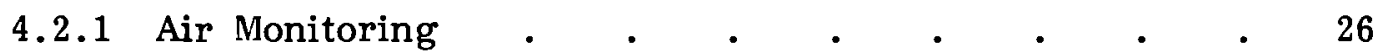

4.2.2 Gamma Radiation Monitoring . . . . . . . $\quad$ • 28

4.2.3 Contamination Control Surveys . . . . . . . 30 
4.3 EXPOSURE CONTROL IN URANIUM MILLS • . $\quad$ • $\quad$ - 31

4.3.1 Process Safety Engineering • • • • • • . $\quad$ • 31

4.3.2 Respiratory Protection . . . . . . . . . 33

4.3.3 Contamination Control and Protective Clothing . . 34

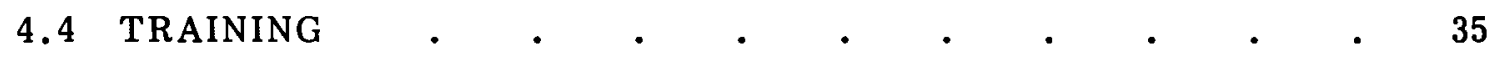

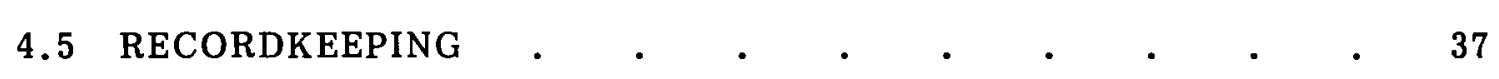

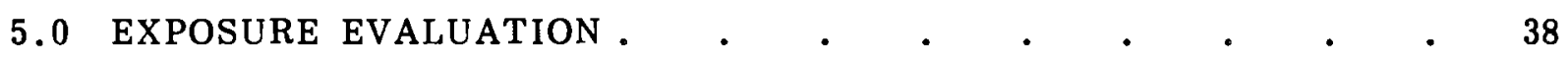

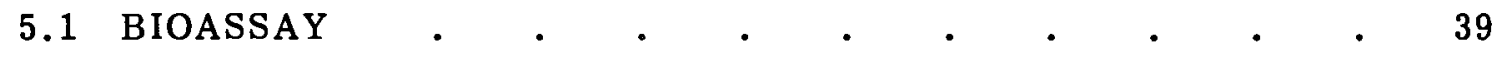

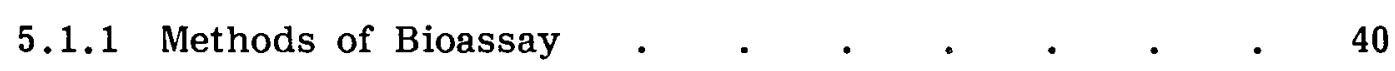

5.1.2 Action Based on Bioassay Results _. . . . . 43

5.2 ASSESSMENT OF EXTERNAL GAMMA EXPOSURES . • . 43

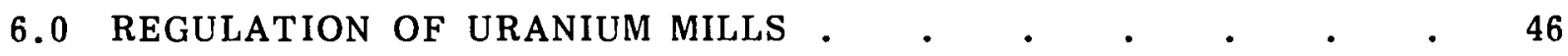

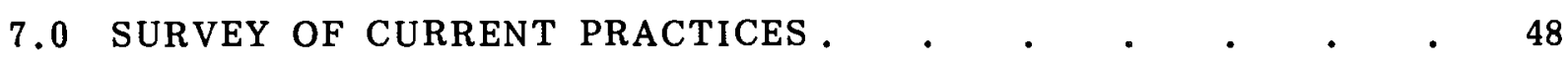

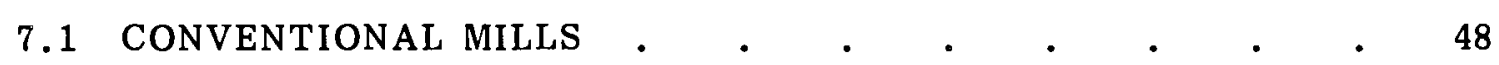

7.2 SOLUTION MINING/YELLOWCAKE PRODUCTION PROCESSES . 51

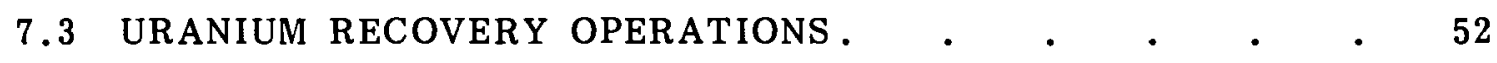

7.4 HEAP LEACHING PROCESSES . $. \quad . \quad$. $\quad . \quad$. $\quad . \quad 53$

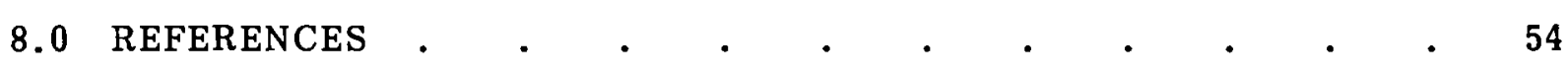




\section{FIGURES}

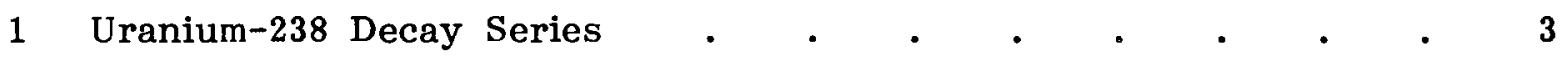

2 Uranium Mills in the United States Operating as of $1 / 1 / 80$. $\quad$ - 6

3 Flow Diagram of Basic Conventional Milling Steps . $\quad$ - $\quad$ • $\quad 10$

\section{TABLES}

$\begin{array}{lllllllllllll} & \text { Currently Operating Uranium Production Mills } & \text { • } & \text { • } & & \text {. } & & & & \end{array}$

2 Selected Methods for Determining Radon Concentrations

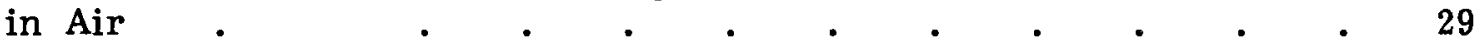

3 Selected Methods for Determining Radon Daughter

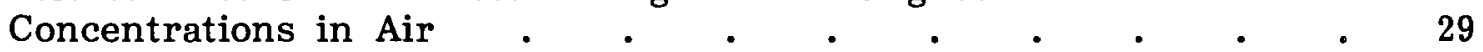

4 Suggested Facility Monitoring Locations in Mills and

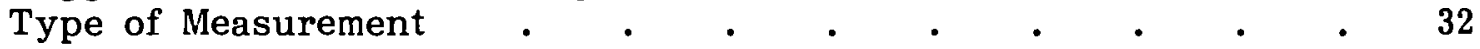

5 Corrective Actions on Urinary Uranium Concentration Results . 44

6 Corrective Actions Based on In Vivo Results . . . . . . . 45

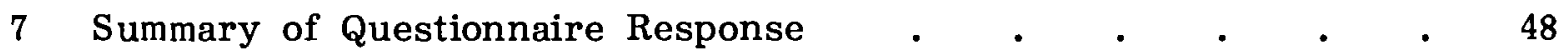

8 Conventional Mills Production and Employment Data $\quad$ • $\quad$ • $\quad 49$

$9 \quad$ Solution Mining Production and Employment Data . . . $\quad$ • $\quad$. 51

10 Uranium Recovery Operations Production and Employment Data . 52 


\subsection{INTRODUCTION}

The United States Uranium Registry (USUR) was founded in 1978 to investigate potential hazards from occupational exposure to uranium and to assess the need for special health-related studies of uranium workers. The need for information on the behavior and effects of uranium in man was reinforced at the U.S. Energy Research and Development Administration's Conference on Occupational Health Experience with Uranium in 1975 . In response to this need, the U.S. Department of Energy provided funding to the Hanford Environmental Health Foundation to establish the USUR. Pacific Northwest Laboratory was later selected to provide health physics technical support to the USUR.

The major goals of the Registry are to:

- characterize the processes and the occupational health aspects of the uranium fuel cycle

- determine the concentration and distribution of uranium and its decay daughters in the tissues of exposed workers

- identify populations suitable for special health-related studies.

Personnel working for the USUR have visited 35 uranium production and processing facilities to collect information toward accomplishment of these goals. Facilities visited include currently operating commercial uranium facilities (mines, mills, conversion plants, enrichment plants, and fuel fabrication plants) and several noncommercial and inactive uranium facilities. Information obtained to date covers general facility descriptions, process descriptions, radiological exposure data, regulatory requirements, radiological health practices, nonradiological exposure conditions, and occupational medicine programs. The information-gathering phase of the program reinforced the original beliefs of the USUR staff that a post-mortem tissue program for uranium workers was needed. The current lack of relevant information on 
the deposition, distribution, and retention of various uranium compounds in man greatly increases the difficulty of developing appropriate standards for uranium exposure and, consequently, worker protection policies and regulations. The autopsy tissue analysis program will in due course provide that information.

\subsection{URANIUM MILLS AND NATURAL RADIOACTIVITY}

Uranium is a heavy metal of slight radioactivity which is found as a trace oxide in numerous mineral formations, rocks, and sands throughout the earth's crust. Naturally occurring uranium consists of 99.28 percent ${ }^{238} \mathrm{U}$, 0.72 percent ${ }^{235} \mathrm{U}$, and about 0.0054 percent ${ }^{234} \mathrm{U}$.

Uranium mills process uranium ores that are mined from the ground. The uranium ore is crushed so that the small percentage of uranium in the rock can be extracted and concentrated. A semi-refined product commonly known as "yellowcake" is precipitated, dried, and packaged into drums for shipment to conversion plants and further chemical processing. Eventually the uranium is enriched, converted into metal oxide pellets, and loaded into rods for use as fuel elements at nuclear power plants.

Uranium-238 is a long-lived parent of a chain of radioactive decay products which include thorium, radium, radon gas, and radon daughter products (Figure 1). The isotopes of this series emit alpha, beta, and gamma radiation of various energies and intensities. Although the concentration of radioactivity in uranium ore is low, special precautions are required to protect uranium mill workers from unnecessary and potentially harmful exposure to radioactivity in uranium ore dust, concentrate streams, and yellowcake product. Radiological protection is achieved when the source of the activity is understood, controlled, and monitored by the mill workers. 


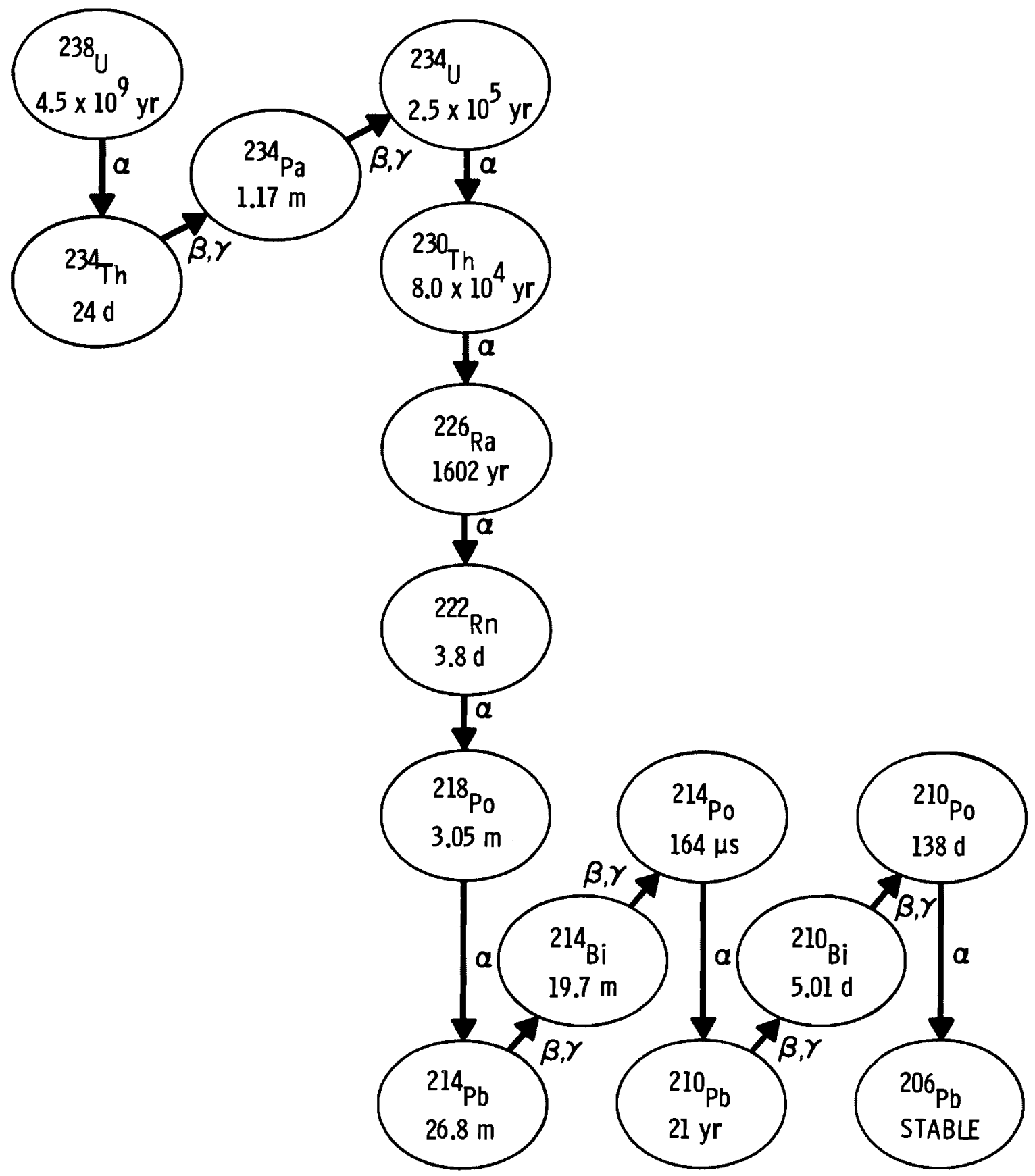

FIGURE 1. Uranium-238 Decay Series 


\subsection{SCOPE}

The purpose of this report is to describe the operation of conventional and unconventional uranium milling processes, the potential for occupational exposure to ionizing radiation at the mill, methods for radiological safety, methods of evaluating occupational radiation exposures, and current government regulations for protecting workers and ensuring that standards for radiation protection are adhered to. In addition, a survey of current radiological health practices is summarized.

Note added at printing: This report was prepared shortly after the uranium industry experienced peak production and employment levels. More recently, however, this industry suffered a major recession and substantial production declines due to reduced demand for refined uranium yellowcake, cancellation of orders, and lower market prices. As a result, a number of facilities were closed down or operated at reduced production levels. The production data and employment levels for the uranium milling industry presented in this report are applicable to the time period 1980-1981. 


\subsection{PROCESS DESCRIPTIONS}

Uranium mills are located near major uranium deposits in the United States. These deposits are found primarily in the western states: New Mexico, Colorado, Wyoming, and Utah. Additional uranium is extracted from deposits in Washington, Texas, and Arizona, and as a by-product of phosphoric acid production in Florida and Louisiana (Figure 2).

A number of different industrial processes have been implemented at uranium mills to extract and concentrate $\mathrm{U}_{3} \mathrm{O}_{8}$ from the feedstock material (Table 1). The chemistry of each process is matched with the geochemical characteristics of the ore feedstock material. Present-day uranium milling operations are sometimes classified into two general categories based on the origin of the feedstock:

- conventional mills, which process uranium ores mined from underground or open-pit mines

- unconventional mills, which process uranium-bearing solutions from in-situ solution mining, uranium recovery operations, or heap leaching operations.

At present, conventional milling operations account for approximately 90 percent of the uranium yellowcake produced in the United States. Solution mining produces about 6 percent of the total, uranium recovery from phosphoric acid processing about 3 percent, and heap leaching about 1 percent of the total U.S. production. In addition, uranium is recovered as a by-product of copper, beryllium, and vanadium mining and smelting.

The following is a brief description of the major process flows at 1) conventional and 2) unconventional mills. 


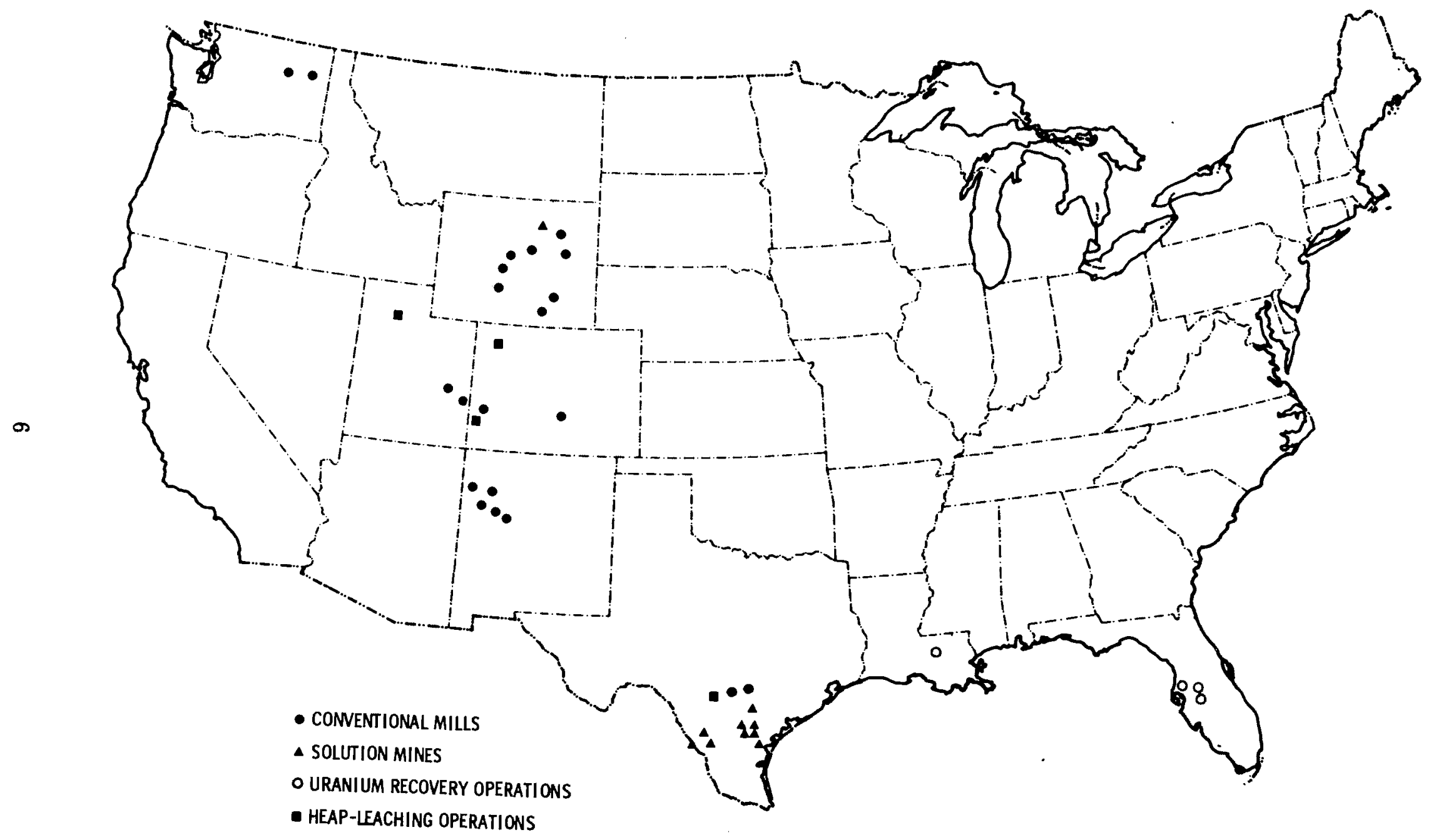

FIGURE 2. Uranium Mills in the United States Operating as of 1/1/80 (derived from DOE 1980) 
TABLE 1. Currently Operating Uranium Production Mills ${ }^{\text {(a) }}$

\begin{tabular}{|c|c|c|c|c|c|}
\hline & Mill & Location & Process Used & $\begin{array}{c}\text { Ore Processing } \\
\text { Capacity } \\
\text { (tons/day) } \\
\end{array}$ & $\begin{array}{l}\text { Year of } \\
\text { Startup }\end{array}$ \\
\hline Con & hventional Mills & & & & \\
\hline 1) & Anaconda Copper Company & Grants, New liexico & $\begin{array}{l}\text { Acid Leach, } \operatorname{CcD}^{(b)} \text {, } \\
\text { Solvent Extraction }\end{array}$ & 6000 & 1953 \\
\hline 2) & Atlas Minerals Corp. & Moab, Utah & $\begin{array}{l}\text { Acid I,each, Solvent } \\
\text { Extraction } \\
\text { Alkaline Leach, } \\
\text { resin-in-pulp }\end{array}$ & 1400 & 1956 \\
\hline 3) & Bear Creek Uranium Co. & Powder River Basin, Wyoming & $\begin{array}{l}\text { Acid Leach, } \mathrm{CCD} \text {, } \\
\text { Solvent Extraction }\end{array}$ & 2000 & 1977 \\
\hline 4) & Chevron Resources Co. & Hobson, Texas & $\begin{array}{l}\text { Acid Leach, } C C D, \\
\text { Solvent Extraction }\end{array}$ & 2500 & (c) \\
\hline 5) & Conoco-Pioneer Nuclear & Falls City, Texas & $\begin{array}{l}\text { Acid Leach, CCD, } \\
\text { Solvent Extraction }\end{array}$ & 3400 & 1971 \\
\hline 6) & Cotter Corporation & Canon City, Colorado & $\begin{array}{l}\text { Alkaline Leach, } \\
\text { Caustic Pre- } \\
\text { cipitation }\end{array}$ & 1200 & 1958 \\
\hline 7) & Dawn Mining Company & Ford, Washington & $\begin{array}{l}\text { Acid Leach, CCD, } \\
\text { Column Ion Exchange }\end{array}$ & 450 & 1957 \\
\hline 8) & Exxon Minerals Company & Powder River Basin, Wyoming & $\begin{array}{l}\text { Acid Leach, } C C D, \\
\text { Solvent Extraction }\end{array}$ & 3200 & 1972 \\
\hline 9) & $\begin{array}{l}\text { Federal-American } \\
\text { Partners }\end{array}$ & Gas Hills, Wyoming & Acid Leach, Eluex & 950 & 1959 \\
\hline 10) & Kerr-McGee Nuclear Corp. & Grants, New Mexico & $\begin{array}{l}\text { Acid Leach, CCD, } \\
\text { Solvent Extraction }\end{array}$ & 7000 & 1958 \\
\hline 11) & Pathfinder Mines Corp. & Gas Hills, Wyoming & Acid Leach, Eluex & 2500 & 1956 \\
\hline 12) & Pathfinder Mines Corp. & Shirley Basin, Wyoming & $\begin{array}{l}\text { Acid Leach, CCD, } \\
\text { Column Ion Exchange }\end{array}$ & 1800 & 1971 \\
\hline 13) & Petromics Company & Shirley Basin, Wyoming & $\begin{array}{l}\text { Acid Leach, } \mathrm{CCD} \text {, } \\
\text { Solvent Extraction }\end{array}$ & 1500 & 1962 \\
\hline 14) & Rio Algom Corporation & LaSal, Utah & $\begin{array}{l}\text { Alkaline Leach, } \\
\text { Caustic Pre- } \\
\text { cipitation }\end{array}$ & 750 & 1972 \\
\hline 15) & $\begin{array}{l}\text { Sohio Natural Resources } \\
\text { Company }\end{array}$ & Cebolleta, New Mexico & $\begin{array}{l}\text { Acid Leach, } C C D \text {, } \\
\text { Solvent Extraction }\end{array}$ & 1600 & 1976 \\
\hline 16) & Union Carbide Corp. & Uravan, Colorado & $\begin{array}{l}\text { Acid Leach, } C C D \text {, } \\
\text { Column Ion Exchange }\end{array}$ & 1300 & 1950 \\
\hline 17) & Union Carbide Corp. & Natrona County, Wyoming & Acid Leach, Eluex & 1400 & 1960 \\
\hline 18) & United Nuclear Corp. & Church Rock, New Mexico & $\begin{array}{l}\text { Acid Leach, CCD, } \\
\text { Solvent Extraction }\end{array}$ & 3000 & 1977 \\
\hline 19) & $\begin{array}{l}\text { United Nuclear-Homestake } \\
\text { Partners }\end{array}$ & Grants, New Mexico & $\begin{array}{l}\text { Alkaline Leach, } \\
\text { Caustic Pre- } \\
\text { cipitation }\end{array}$ & 3400 & 1958 \\
\hline 20) & Western Nuclear, Inc. & Jeffrey City, Wyoming & Acid Leach, Eluex & 1700 & 1957 \\
\hline 21) & Western Nuclear, Inc. & Wellpinit, Washington & $\begin{array}{l}\text { Acid Leach, CCD, } \\
\text { Solvent Extraction }\end{array}$ & 2000 & 1978 \\
\hline
\end{tabular}




\section{TABLE 1. (continued)}

Mill

Solution Mining Operations

1) Everest Mineral Corp.

2) IEC Corp.

3) Mobil Oil Corp.

4) Union Carbide Corp.

5) United States Steel Corp.

6) U.S. Steel-Niagara Mohawk

7) Uranium Resource, Inc.

8) Wyoming Mineral Corp.

9) Wyoming Mineral Corp.

10) Wyoming Mineral Corp.

Uranium Recovery Operations (d)

1) Freeport Uranium Recovery Corp.

2) Uranium Recovery Corp.

3) Wyoming Mineral Corp.

4) Gardinier, Inc.

5) New Wales Chemical, Inc. (e)

Heap Leaching Operations $(d)$

1) Durita Development Corp.

2) Solution Engineering, Inc.

3) Union Carbide Corp.

4) Wyoming Mineral Corp.
Location

Year of

Startup

(c)

Three Rivers, Texas

(c)

Bruni, Texas

(c)

Palangana, Texas

(c)

George West, Texas

(c)

George West, Texas

1975

Bruni, Texas

Bruni, Texas

1977

Three Rivers, Texas

1977

Irigaray, Wyoming

(c)

Uncle Sam, Louisiana

1978

Mulberry, Florida

1975

Pierce, Florida

1978

Tampa, Florida

1979

Mulberry, Florida

1979

Naturita, Colorado

Falls City, Texas

(c)

Maybell, Colorado

(c)

Bingham Canyon, Utah

(a) The following references were used to compile this table:

1) Statistical Data of the Uranium Industry, GJO-100 (USDOE 1980).

2) Final Generic Environmental Impact Statement on Uranium Milling, NUREG-0706 (USNRC 1980).

(b) Countercurrent decantation.

(c) Not available.

(d) This listing is of commercially operating sites; there are numerous research and development and pilot projects which are not listed.

(e) Began commercial operation during 1980 . 


\subsection{CONVENTIONAL MILLING PROCESSES}

Conventional uranium milling involves ore crushing and grinding, chemical leaching and separation, recovery of uranium by precipitation, drying, and packaging. However, the specific chemicals and type of equipment used to accomplish these steps can vary in considerable detail from one mill to another. Process variations are necessitated either by the geochemical composition of the ore, or developments in new technology with improved separation efficiencies. The primary milling processes currently utilized in the industry are:

- acid leach, solvent extraction

- acid leach, ion exchange

- acid leach, Eluex separation, or

- alkaline leach, resin-in-pulp concentration.

Approximately 80 percent of the conventional mills in the U.S. use an acid leach process, and the remaining 20 percent use an alkaline leach process. Acid leach is preferred for ores with low lime content (usually 12 percent or less). The alkaline (or carbonate) leach process is used for ores with high lime content that would otherwise require large quantities of acid for neutralization. The most common process is acid leach with solvent extraction. Currently 11 out of 22 mills operating use this process (Table 1).

The four basic divisions of the conventional milling process flow are:

- ore handling and preparation

- extraction

- concentration and purification

- precipitation.

The variations in chemical process for these divisions are diagrammed in Figure 3. The following sections provide a detailed discussion of the steps involved in each process division.

\subsubsection{Ore Handling and Preparation}

Uranium-bearing ore is transported to the mill and weighed. The ore is then analyzed for moisture content and percentage $\mathrm{U}_{3} \mathrm{O}_{8}$. An accurate assessment of the moisture content is important for several reasons. First, the amount of ore fed into the mill is determined according to dry-ton 
|ORE HANDLING AND PREPARATION $\mid$ EXTRACTION $\left|\begin{array}{c}\text { CONCENTRATION AND } \\ \text { PURIFICATION }\end{array}\right|$ PRECIPITATION

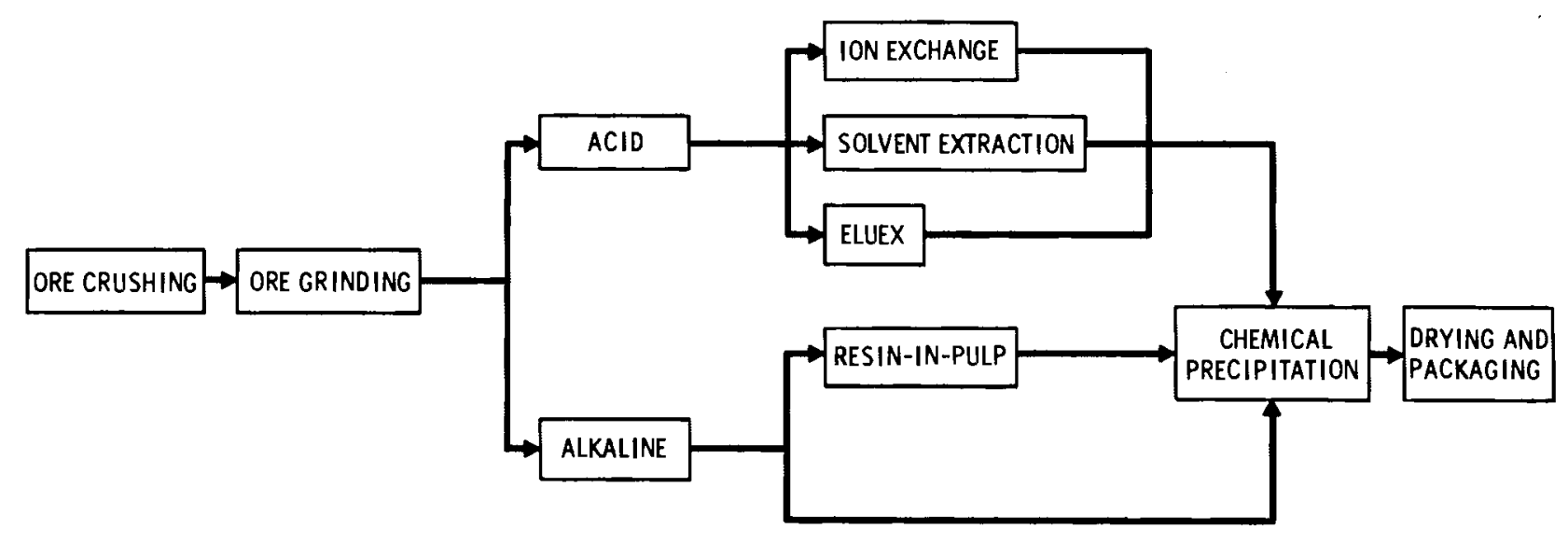

FIGURE 3. Flow Diagram of Basic Conventional Milling Steps

equivalents. Secondly, dust control becomes increasingly important as the moisture content of the ore decreases. In some cases the amount of moisture present can influence the selection of chemical processes used to separate out the uranium.

The ore is dumped into a receiving area, where individual lots of ore can be segregated and processed according to need. The ore is then selected by the operator and moved by front-end loaders to a screen-like "grizzly," where the ore can drop into the primary crusher. The ore is often blended with lots from different ore pads. The process of blending ore is performed to ensure that the feed material has physical and chemical characteristics that will enable the $\mathrm{U}_{3} \mathrm{O}_{8}$ extraction process to proceed with maximum efficiency.

The primary crusher chops the ore into pieces that are less than $15 \mathrm{~cm}$ ( 6 inches) in diameter. A secondary crusher is employed to reduce the ore to pebbles $2-4 \mathrm{~cm}(0.8-1.5$ inches) in diameter. Either impact-type or cone gyratory crushers may be used, depending upon the hardness of the ore. Air exhaust hoods and water sprays are located at each transfer point in the 
crushing operation for dust control. The exhaust air passes through a dust collector prior to its discharge into the atmosphere.

Upon leaving the secondary crusher, the crushed ore is transferred along a broad conveyor belt system to the sample station and the fine ore storage bins. Samples are taken to determine the $\mathrm{U}_{3} \mathrm{O}_{8}$ content of the crushed ore. The fine ore storage bins generally have a capacity of about twice the rated daily mill capacity.

Ore from the storage bins is transferred via a conveyor belt system to the grinding circuit. Ore for the alkaline leach process requires finer grinding (200 mesh) than ore for the acid leach process (28 mesh). Ball or rod mills are used to wet grind ores into an ore slurry that is 50 to 70 percent solids.

\subsubsection{Extraction}

Up to this point in the process, only water has been added to the crushed ore. It is now ready for chemical extraction of $\mathrm{U}_{3} \mathrm{O}_{8}$. The ore slurry is pumped to the leaching agitators, where sulfuric acid $\left(\mathrm{H}_{2} \mathrm{SO}_{4}\right)$ and the oxidants sodium chlorate $\left(\mathrm{NaClO}_{3}\right)$ or manganese dioxide $\left(\mathrm{MnO}_{2}\right)$ are added if the process is acid leach. If the process is alkaline leach, then the oxidant sodium carbonate $\left(\mathrm{Na}_{2} \mathrm{CO}_{3}\right)$ is added.

In the acid leaching process, a number of leaching tanks are arranged in series for the uranium slurry to pass through. Metals, such as uranium, that solubilize in sulfuric acid, are dissolved. The addition of oxidant speeds up the leaching and improves the recovery of uranium. The slurry is continuously mixed for 3 to 20 hours, depending upon the dissolution characteristics of the ore.

The ore slurry from the acid leaching tanks then undergoes a liquidsolid separation process or a sand-slime separation process. The liquid-solid separation process used in 13 of 17 acid leach mills is a countercurrent decantation ( $C C D$ ) circuit designed to separate the uranium-bearing solution from undissolved solids. Water is the principal washing medium. Flocculants (chemical agents) are usually added to this circuit to accelerate the settling 
rates of undissolved solids. Following the liquid-solid separation process, the liquid phase containing the uranium is clarified by passage through sand filters, activated-carbon filters, or anthracite coal filters. The solution is then ready for the concentration and purification phase.

Some acid leach mills use a sand-slime separation circuit where the product is a slurry containing about five to seven percent solids. These mills utilize cyclone classifiers for centrifugal separation of the heavier sand particles from the slime. The sand exits the phase from the bottom of the cyclones. The sand slurry is fed into a rake classifier circuit, where it can be washed with an acidic water solution using counter-current decantation. The uranium separates from the sand and is passed on to the concentration and purification phase. The barren sand tailings are pumped onto piles for dewatering.

The overall extraction process for the alkaline leach mills is similar to acid leach mills. Leaching of uranium from ore occurs in a series of agitated tanks, and the ore slurry from the tanks undergoes a liquid-solid separation process to isolate the uranium-bearing solution from the undissolved solids.

\subsubsection{Concentration and Purification}

This step of the milling process uses one of several chemical methods to concentrate and purify the feed solution from the extraction step. The methods vary somewhat between acid and alkaline mills.

Acid Leach Mills. Acid leaching is a nonselective process that results in the dissolution of elements other than uranium and the production of a lowgrade uranium solution. This low-grade uranium solution is concentrated and purified by one of three processes: solvent extraction, ion exchange, or Eluex. The process used by individual mills is determined by ore characteristics. A brief description of each of the three processes follows:

- The solvent extraction process is used in 10 out of the 17 acid leach mills. Uranium in the feed solution is extracted into an organic phase and subsequently stripped into an aqueous phase. The solvent extraction circuit consists of a series of extraction tanks with 
the feed solution and organic solvent flowing countercurrently. In this first phase, sulfate ions from the organic solution are exchanged for uranium ions from the feed solution. In the second phase, the organic solvent solution containing the uranium is mixed with a concentrated ammonium sulfate, chloride, or sodium carbonate stripping solution, which results in the uranium ions being transferred to the aqueous solution. The aqueous ammonium sulfate, chloride, or sodium carbonate solution now contains the uranium in a concentrated form.

- The ion exchange process for concentrating uranium can be used for the treatment of both pulps and clarified feed solutions from the extraction phase. Currently, three acid leach mills use this process. Feed solutions or pulps pass through the-ion exchange columns where dissolved uranium ions are adsorbed into resin beads. A rinsing solution commonly referred to as an eluting solution (chloride, nitrate, bicarbonate, or an ammonium sulfate/sulfuric acid solution) is then passed through the column, stripping the uranium from the resin in a concentrated form.

- The Eluex process is a combination of the ion exchange and solvent extraction processes, and is currently in use in four mills. Slime pulp from the extraction phase is contacted with ion-exchange resins, which are then eluted with sulfuric acid. The sulfuric acid solution containing the uranium is placed into a solvent extraction process for further concentration. Advantages of the Eluex process are attainment of a purer end-product and elimination of the requirements for nitrate and chloride agents.

Alkaline Leach Mills. The alkaline leach process has a greater selectivity for extracting uranium than the acid leach process. Therefore, three of four alkaline leach mills have no concentration and purification step. The clarified solutions from the extraction phase proceed directly to precipitation. The alkaline leach process of the dual acid-alkaline leach mill uses a resin-in-pulp (RIP) process for concentrating the uranium. RIP is an ion-exchange type process in which resin-filled cubical baskets are moved up and down in a 
tank containing uranium-bearing pulp from the extraction phase. Uranium is extracted by circulating eluant and wash solutions through the resin in a series of tanks.

\subsubsection{Precipitation and Packaging}

The acid strip solution, which now contains the concentrated uranium, is pumped to the precipitation circuit, where uranium is caused to drop out of the solution in a solidified form. For acid leach mills, the feed solution to the precipitation phase is an acidified chloride, nitrate, or sulfate solution enriched in uranium. An alkaline carbonate solution is the feed for the precipitation phase of the alkaline leach mills.

There are three methods of precipitating yellowcake in acid leach mills. One method is a two-stage process used when iron and sulfate impurities are significant. In the first stage, lime is added to the feed material to attain a $\mathrm{pH}$ of about 4.0 and separate iron hydroxide and sulfate impurities. Next, caustic soda (sodium hydroxide), magnesia, or ammonia is added to attain $\mathrm{pH}$ of 6.5 to 8.0 and precipitate the uranium in the form of ammonium diuranate, $\left(\mathrm{NH}_{4}\right)_{2} \mathrm{U}_{2} \mathrm{O}_{7}$. A second method, the addition of hot air and ammonia to an appropriate $\mathrm{pH}$, will precipitate an ammonium diuranate compound. A third method is precipitation with hydrogen peroxide $\left(\mathrm{H}_{2} \mathrm{O}_{2}\right)$. The latter method can be used when a purer product is desired. The uranium is precipitated as a hydrated uranium peroxide $\left(\mathrm{UO}_{4} \cdot 2 \mathrm{H}_{2} \mathrm{O}\right)$.

The principal method of precipitating uranium from the alkaline feed material is addition of caustic soda (sodium hydroxide) to a $\mathrm{pH}$ of 12.0. The uranium will precipitate as an insoluble sodium diuranate compound $\left(\mathrm{Na}_{2} \mathrm{U}_{2} \mathrm{O}_{7}\right)$. If sodium levels are too high to allow marketing of $\mathrm{U}_{3} \mathrm{O}_{8}$, the sodium can be removed by dissolving the sodium diuranate in sulfuric acid and re-precipitating with ammonia, yielding an ammonium diuranate compound.

The final stages in the production of $\mathrm{U}_{3} \mathrm{O}_{8}$ are dewatering, filtering, washing, drying, and packaging. These stages are similar for both acid and alkaline leach mills. The precipitated yellowcake is dewatered in thickeners, filtered, and washed. The resulting filter cake is then dried in either a continuous steam-heated dryer at $100^{\circ}$ to $150^{\circ} \mathrm{C}$, or a multiple-hearth dryer at $370^{\circ}$ to $538^{\circ} \mathrm{C}$. Drying at lower temperatures $\left(100^{\circ}\right.$ to $\left.150^{\circ} \mathrm{C}\right)$ results in a 
yellow-colored product high in ammonium diuranate (ADU). Mills that dry their product at higher temperatures $\left(370^{\circ}\right.$ to $538^{\circ} \mathrm{C}$ ) will convert $\mathrm{ADU}$ to a greenish black powder high in uranium oxide $\left(\mathrm{U}_{3} \mathrm{O}_{8}\right)$. Drying the product at high temperatures also decomposes many of the impurities (such as sulfates). The dry product contains 80 to 96 percent uranium as $\mathrm{U}_{3} \mathrm{O}_{8}, \mathrm{UO}_{3}$, and/or ammonium diuranate. Lastly, the yellowcake product is crushed, if necessary, and packaged in 55-gallon steel drums for shipment. Product weight per drum is 300 to $400 \mathrm{~kg}$, depending upon the product density.

Conventional mills are rated according to their ore-processing capacity (tons of ore processed per day or TPD). The largest conventional mill has a rated capacity of $7000 \mathrm{TPD}$, the smallest 450 TLD (Table 1).

\subsection{UNCONVENTIONAL MILLING PROCESS}

The three major unconventional milling processes in the United States are solution (in-situ) mining, uranium recovery operations, and heap leaching. These processes account for approximately 10 percent of the total yellowcake production, but could contribute considerably larger percentages of the total yellowcake production if uranium ore deposits obtained by conventional mining methods become further depleted.

As of January $1,1980,10$ solution mines were operating, primarily in southern Texas. Four uranium recovery operations were located in Florida and Louisiana, and four heap-leaching operations were scattered throughout the western United States. The yellowcake production capacity of unconventional operations ranges from 125 to 500 tons (113 to $454 \mathrm{t}$ ) per year (in the range of small-capacity conventional mills).

\subsubsection{Solution Mining}

Most of the commercially active solution mining is concentrated in southern Texas near the Gulf coast (see Table 1). Solution mining involves the injection of a leach solution into a subterranean uranium-bearing ore body to dissolve and complex the uranium, the mobilization of the uranium complex formed, and the surface recovery of the uranium from uranium-bearing solution by pumping the leaching solution back to the mill. Depending on the ore type, either an acidic or a basic oxidizing leach solution is injected into and 
withdrawn from the ore body via sets of wells. Ore grades are highly variable, but usually contain less than 1 percent uranium by weight.

Once the leach solution is pumped from the ground, it undergoes concentration and purification. Most locations use ion exchange columns to concentrate the uranium, followed by ammonium precipitation. The yellowcake precipitate is clarified, filtered, dried, and packaged by a method similar to those in conventional mills.

\subsubsection{Uranium Recovery Operations}

Large deposits of phosphate ores in Florida and Idaho are mined and processed into phosphate products (such as fertilizer). These deposits generally contain 50 to $200 \mathrm{ppm}$ uranium (0.005-0.02 percent), or only about five to ten percent of the uranium concentration found in commercially mined ores. However, the vast phosphate reserves are gaining new importance as a source for by-product uranium. Currently, there are five plants with the capability to extract uranium from wet phosphoric acid.

In commercial phosphate production, sulfuric acid is used to digest the phosphate ore yielding dilute phosphoric acid (30 percent $\mathrm{P}_{2} \mathrm{O}_{5}$ ) and calcium sulfate. Uranium is extracted from this dilute $\mathrm{P}_{2} \mathrm{O}_{5}$. Uranium extraction plants borrow the phosphoric acid from the commercial phosphate plants, extract the uranium, and return the phosphoric acid back to the phosphate plants. A solvent extraction process is used to extract uranium from the $\mathrm{P}_{2} \mathrm{O}_{5}$. Because of the high humic (organic material) content in phosphate ores, which interferes with uranium extraction, separation of the organic material is necessary prior to uranium recovery.

\subsubsection{Heap-Leaching}

The heap-leaching process can be used on old copper, vanadium, and uranium tailings piles and low-grade ore dumps, or when the ore body is small or situated far from a conventional mill. It involves leaching of ore or tailings either by gravitational flow through an open pile or by flooding a confined ore pile.

The basic process involves percolating a seven to ten percent $\mathrm{H}_{2} \mathrm{SO}_{4}$ solution through the ore or tailings piles with the enriched solution collected 
from the bottom of the pile. Some operations use plain water as the leaching solution. The enriched (uranium-bearing) solution then can either be shipped to a conventional mill and added to the concentration and purification phase or processed by solvent extraction or ion exchange and precipitated at the heap-leaching site. 


\subsection{OCCUPATIONAL RADIATION EXPOSURE}

Uranium mills process ore containing relatively small amounts of radioactive materials. Radiation exposures to mill workers occur primarily from exposure to gamma, alpha, and beta-emitting members of the uranium series decay chain (Figure 2) which are present in the mill feedstock, process solutions, and yellowcake product. The greatest potential for occupational radiation exposure in uranium mills results from inhalation of uranium and its decay products in aerosol suspensions. Of secondary importance is the occupational exposure attributable to external gamma and beta radiation.

In the early days of the Manhattan Project, uranium was not considered to be a hazardous material because of its low specific activity and low gamma emission rate. Little was known about the biological effects of alpha and beta particles. The importance of radon and its daughter products was not fully realized until many years later when underground uranium miners began experiencing an increased lung cancer mortality. Throughout the $1950 \mathrm{~s}$, the demand for uranium for the nuclear weapons program stimulated a rapid increase in uranium exploration activities. Several mills were constructed and operated during this period.

The first radiological surveys at uranium mills were performed with simple Geiger-Mueller (G-M) counters and scintillometers. The primary concern was directed toward external gamma radiation. Later, radon daughter measurements were performed in the mills by counting air-filter samples with an ion chamber survey meter (Wilde 1975).

Eventually it was determined that the greatest potential for occupational radiation exposure in uranium mills was attributable to inhalation of airborne particulate material containing uranium or its decay series daughters. These materials include the long-lived alpha emitters (uranium, thorium, and radium) present in ore dust, the short-lived decay progeny of radon gas, and yellowcake dust (concentrated uranium).

In the following sections, the various source materials and the potential for occupational radiation exposure are discussed for each of the four stages of uranium milling: ore handling and preparation, extraction, concentration and purification, and precipitation. 


\subsection{ORE HANDLING AND PREPARATION}

The most important source of occupational radiation exposure to workers in the ore handling and crushing areas of the mill is inhaled uranium ore dust. Dust is generated by ore hauling equipment and mechanical rockcrushing equipment. There is no ore handling or crushing phase at unconventional milling operations.

The major long-lived nuclides in ore dust are ${ }^{238} \mathrm{U},{ }^{234} \mathrm{U},{ }^{230} \mathrm{Th},{ }^{226} \mathrm{Ra}$, and ${ }^{210}$ Po. These long-lived alpha emitters are present in approximate equilibrium in dust generated in the mill from rock crushing, grinding, sizing, sampling, and transfer operations.

Moist ores generally result in smaller quantities of airborne dust. Dust levels in the work areas are controlled by a dust collection and removal system (and supplemental water sprays, if necessary).

Uranium ore dusts are characterized by their large particle size $(2-30 \mu \mathrm{m}$ activity median aerodynamic diameter, or AMAD). Such relatively large aerosols tend to become trapped in the upper airways before they can enter the deep lung. Most radionuclides present in uranium ore dust are insoluble in lung fluids and are removed from the body at a very slow rate (Kalkwarf 1979, Fisher 1982). In general, the specific activity of uranium ores is low, and radiation exposures received by crusher workers due to external penetrating radiation or inhaled alpha- and beta-emitting dust particles are usually maintained well below currently established guidelines for radiation protection. Nonetheless, federal regulations limit the permissible concentration of radioactive materials in the air that is breathed. Operational guidelines have been derived in terms of maximum permissible concentrations (MPCs) which, during a 40-hour-per-week occupational exposure, should not permit the dose to certain important body organs from inhalation of radioactive materials to exceed maximum permissible levels. Current MPCs for individual radionuclides in air and water and for restricted (occupational) areas and unrestricted areas (such as those that are accessible by members of the general public) are given in Title 10, Part 20 of the Code of Federal Regulations (CFR 1980). Separate values are provided for soluble (in body fluids) and insoluble forms 
of the radionuclides. The estimated degree of hazard associated with exposure to radionuclides is reflected in these values; the lower the MPC, the more hazardous the radionuclide. Among members of the ${ }^{238} \mathrm{U}$ decay series, the radionuclide with the lowest MPC is ${ }^{230} \mathrm{Th}$.

Since 1960, the Code of Federal Regulations has contained a special provision for the limiting value of a mixture of radionuclides consisting of ${ }^{238} \mathrm{U}$ and its daughters in uranium ore dust prior to the chemical separation of uranium from the ore at the mill. The operational limits for airborne uranium ore dust according to this provision are currently given in Note 4 of Appendix B (10 CFR Part 20) as $10^{-10} \mu \mathrm{Ci} / \mathrm{m} \ell$ gross alpha activity and $5 \times 10^{-11} \mu \mathrm{Ci} / \mathrm{ml}$ natural uranium in air. The use of these special MPCs has been favored by the uranium industry, since it is difficult to chemically separate the uranium series radionuclides and measure the activity of each radionuclide individually.

Another potential occupational exposure in the ore handling operations is the inhalation of radon and radon daughters. Radon and its short-lived daughters $\left({ }^{218} \mathrm{Po},{ }^{214} \mathrm{~Pb},{ }^{214} \mathrm{Bi}\right.$, and $\left.{ }^{214} \mathrm{Po}\right)$ are present wherever radium $\left({ }^{226} \mathrm{Ra}\right)$ is found. Radon is a noble gas and is thus chemically inert. It migrates easily from radium-bearing materials and may collect in confines of the mill such as the area beneath the crushing machinery.

Radon's relatively short half-life allows daughter products to form in the air. These decay products attach to dust particles, or they can be inhaled directly as free ions. Inhaled radon daughters deposit most of their energy in the tracheobronchial airways, and present some degree of hazard to workers.

It is possible that the greatest health hazards facing crusher workers are nonradiological in nature: accidents involving machinery and equipment, and inhalation of silica dust. Most mills have dust collection systems in crushing and ore bin storage areas which keep concentrations of silica dust and of the various nuclides in ore dust well below appropriate maximum permissible concentrations. Some mills also require workers to wear respirators when the crusher is in operation, and during cleanup activities. 


\subsection{EXTRACTION PROCESSES}

The uranium is in solution during this phase of the milling process, and therefore of little hazard to workers. Gamma exposures are also relatively insignificant because of the low concentration of photon emitters in the slurry. Nonradiologically, sulfur dioxide and sulfuric acid gases may be vented from leaching tanks. Although airborne concentrations of the gases are not well defined, exposures are thought to be minimal since workers spend little time in this area.

\subsection{CONCENTRATION AND PURIFICATION}

The uranium continues in solution during concentration and purification, and there is little potential for occupational exposure to radioactive materials. During maintenance operation when tanks and equipment have been drained, the potential exists for exposure to deposited ${ }^{226} \mathrm{Ra}$. The hazard appears to be greatest when surfaces are scraped or brushed down, giving the radium an opportunity to become airborne and inhaled by the worker. Nonradiologically, solvent extraction tanks exhaust vapors from the kerosene base liquid. Occupational exposures are therefore low--as long as the ventilation system is intact and functioning properly. Since the extraction solvent is extremely flammable, sprinkler systems and tank release capabilities are utilized to combat the potential problem of fire in the mills.

\subsection{PRECIPITATION AND PACKAGING}

The mill process of greatest concern to health physicists is the precipitation, drying, and packaging area of the mill. Chronic or accidental acute inhalation of yellowcake dust represents the highest potential for occupational exposure at the mill.

Defining the hazard of yellowcake inhalation is a difficult problem since the term "yellowcake" refers to a variety of compounds with different color, chemical composition, and solubility in lung fluids. The final yellowcake product usually comprises the following compounds in varying percentages: ammonium diuranate $\left[\left(\mathrm{NH}_{4}\right)_{2} \mathrm{U}_{2} \mathrm{O}_{7}\right]$, sodium diuranate $\left(\mathrm{Na}_{2} \mathrm{U}_{2} \mathrm{O}_{7}\right)$, uranium trioxide $\left(\mathrm{UO}_{3}\right)$, and uranium oxide $\left(\mathrm{U}_{3} \mathrm{O}_{8}\right)$. The solubilities of the above 
compounds depend not only on chemical composition but also on the nature of the physical and chemical processes used to obtain them (Cooke and Holt 1974). Therefore, yellowcake produced at two different mills may have different solubilities owing to different chemical precipitation processes and drying temperatures.

The precipitated product from the mills is primarily ammonium diuranate (ADU). During the drying process ADU is thermally decomposed to $\mathrm{U}_{3} \mathrm{O}_{8}$ with $\mathrm{UO}_{3}$ as an intermediate product. Generally $\mathrm{UO}_{3}$ is formed at temperatures between $260^{\circ}$ and $400^{\circ} \mathrm{C}$, above $400^{\circ} \mathrm{C} \quad \mathrm{UO}_{3}$ decomposes into $\mathrm{U}_{3} \mathrm{O}_{8}$, and between $650^{\circ}$ and $800^{\circ} \mathrm{C}$ conversion to $\mathrm{U}_{3} \mathrm{O}_{8}$ is complete.

The ADU precipitate is dried in either a steam-heated dryer at $100^{\circ}$ to $150^{\circ} \mathrm{C}$, or in a multiple-hearth furnace at $370^{\circ}$ to $538^{\circ} \mathrm{C}$. Mills using a steamheated dryer produce essentially 100 percent ADU for packaging. The situation is much more complex for mills that use a multiple-hearth furnace to dry the precipitated ADU. The composition of the final yellowcake product is predominantly uranium oxide, although many impurities (nitrates, sulfates, and ammonium compounds) may also be present.

Ammonium diuranate exhibits Class D solubility characteristics (Kalkwarf 1979), whereas yellowcake obtained from high temperature drying operations may exhibit partial Class D and predominantly Class $\mathrm{Y}$ solubility characteristics (Dennis et al. 1982). Thus, any ADU dust inhaled by workers during the drying or packaging process will be readily transported away from the worker's lungs and excreted. For such Class D compounds chemical toxicity constitutes a greater health hazard than potential radiation effects. In contrast, Class $\mathrm{Y}$ compounds are less soluble in the lungs, and are therefore retained in the lungs with long biological clearance half-times. The potential radiation hazard of uranium oxide is of greater importance than its chemical toxicity. The solubility classification scheme for inhaled materials is defined and discussed further in Section 5.0.

Mill workers may be exposed to yellowcake dust during routine operation of dryers, during drum-filling and sealing, and during maintenance on equipment where yellowcake product has accumulated. Dry forms of yellowcake are more likely to become airborne and inhaled by workers than moist compounds or process solutions. 


\subsection{METHODS FOR RADIOLOGICAL PROTECTION}

The objective of a radiological protection program is to maintain radiation exposures to workers as low as can reasonably be achieved. The purpose of this section is to describe general methods by which radiation hazards at uranium mills may be identified and controlled. While it is recognized that uranium mills also release low levels of effluent radioactive materials to the surrounding environment through stack emissions and tailings pond or pile noncontainment, the scope of the present report is limited to indoor protection of mill workers. Five aspects of radiological protection are discussed:

- organizational responsibilities

- facility monitoring

- exposure control

- training

- recordkeeping.

Responsibility for an effective safety program is shared by the mill managers, the Radiation Safety Officer and his assistants, and the workers themselves. An efficient organization structure is essential for establishing and enforcing policy and procedures, procuring essential equipment and qualified personnel, and conducting internal audits and inspections of the radiation protection program.

The most important pathway of exposure for uranium industry workers is the inhalation of radioactive airborne contaminants. Exposure control is achieved through containment and dust control design engineering, the proper use of respirators and protective clothing, and employee training programs. Concentrations of radioactive materials in the breathing air are determined by facility monitoring instrumentation. Recordkeeping involves maintaining records of facility monitoring and exposure evaluation data.

Rigid radiological health practices are a requirement of the operating licenses for uranium production facilities, but inadvertent exposures continue to occur, indicating that further improvements are necessary. In the following paragraphs, the various aspects of a quality radiological protection program are discussed. Methods for evaluating routine or accidental exposures are discussed later. 


\subsection{ORGANIZATIONAL RESPONSIBILITIES}

The foundation of an efficient radiation protection program is strong support and involvement by upper management. The manager should appoint a trained Radiation Safety Officer (RSO) and confer upon him the authority and responsibility necessary to achieve an acceptable level of safety. An effective program will be one that fully complies with applicable laws and regulations--while having minimum impact on mill operation and productivity.

Management should work closely with the radiation protection staff, and provide the financial and technical support required. The Radiation Safety Officer should communicate needed resources, training programs, and procedures, and report on the daily activities of his staff. Open communication is an essential element in a successful program. The RSO should report directly to the resident mill manager. Together the manager and the RSO should develop procedures that constitute the optimum radiological protection program.

The RSO should supervise the health physics technical staff responsible for the routine program. He should insure compliance with regulatory requirements and provide the necessary training needed by all employees at the mill. All mill workers are responsible for adhering to operating procedures and company policies. Accidents or noncompliance should be reported to the RSO. Often the employees can suggest improvements in existing policies and procedures, and work with the RSO to see that the objectives of the radiation protection program are carried out.

It is important to periodically review, audit, and evaluate the effectiveness of the radiation protection program. Quality assurance reviews, under the direction of the mill manager, should be conducted to ensure that program activities are performed in accordance with written procedures.

The U.S. Nuclear Regulatory Commission is currently drafting regulatory guides that pertain to practices at uranium mills for ensuring that occupational radiation exposures will be "as low as reasonably achievable" (ALARA). Mill management and the health physics staff should become familiar with existing and proposed regulatory guides dealing with methods for more effective methods and practices in radiation protection. 


\subsection{FACILITY MONITORING}

Many conditions and processes are monitored at uranium mills. This section describes methods of monitoring the working atmosphere for airborne radioactivity and surveying the facility for external gamma radiation. Personnel monitoring and dose evaluation are discussed later.

Monitoring of working locations in uranium facilities is required by Title 10 of the Code of Federal Regulations. The purpose is to insure that employees are not exposed to levels of radioactivity in excess of established limits. Each licensee is required to perform surveys and measurements of radiation levels or concentrations as may be necessary to comply with the federal regulations. Individual monitoring programs are required to fulfill the specific needs of the facility, and therefore tend to be somewhat nonuniform.

The selection of monitoring locations is determined by consideration of the quantities of radioactive materials in the production processes, their potential for escape from the system into the workplace, and their proximity to the worker. The frequency of sampling is dictated by the magnitude of the measurements routinely obtained so that the higher the results, the more frequently the surveys must be performed. Location and frequency of monitoring and sample collection are determined by the individual mills and are included in the source material license application (subject to approval by the licensing authority). Depending on the specific requirements and potential for worker exposure, sampling may be continuous, daily, monthly, quarterly, or annually. Samples are usually taken at or above the breathing zone level for respirable ore dusts, yellowcake, other chemical forms of uranium, radon, or radon daughters, and at the height of the reproductive organs (one meter) for external gamma radiation.

A discussion of facility monitoring may be divided into three general categories:

- air monitoring

- gamma radiation surveillance

- surveys for surface contamination. 


\subsubsection{Air Monitoring}

There is general agreement that airborne radioactivity represents the major radiological health hazard at uranium mills. The indoor breathing air at uranium mills should be monitored for indication of excessive levels of respirable radioactivity. Three separate exposure categories are considered:

- inhalation of long-lived alpha-emitters (uranium, thorium, and radium) present in uranium ore dust,

- inhalation of the short-lived decay products of radon gas, and

- inhalation of various forms of yellowcake, the composition of which is determined by the chemical process and the drying temperature.

Breathing air should be sampled periodically or continuously, depending upon the degree of hazard present. A variety of instruments may be used. These include both portable and fixed-location air filter pumps, lapel samplers, and instant working level meters. Lapel and high-volume samplers are commonly used during special maintenance activities or in areas of potential release not monitored by fixed-location instruments.

Air filters may be either cellulose-asbestos, membrane-type (millipore), or glass fibre in construction, depending upon the method chosen for radiometric analysis. The two main methods of uranium assay are fluorometry and direct alpha counting. Air concentrations are commonly reported in units of milligrams or microcuries of uranium per cubic meter air.

\subsubsection{Sampling for Long-Lived Alpha Emitters}

The crushing, grinding, and ore storage areas of the mill should be sampled for respirable airborne particulates containing long-lived members of the uranium series decay chain $\left({ }^{238} \mathrm{U},{ }^{234} \mathrm{U},{ }^{230} \mathrm{Th},{ }^{226} \mathrm{Ra}\right)$. The operational limits for airborne uranium ore dust are specified in 10 CFR, Part 20, Appendix $\mathrm{B}$ as $10^{-10} \mu \mathrm{Ci} / \mathrm{m} \ell$ gross alpha activity and $5 \times 10^{-11} \mu \mathrm{Ci} / \mathrm{m} \ell$ natural uranium in air.

Air samples are usually collected using portable or fixed-station air samplers positioned at breathing zone levels. Filters are then removed and 
counted using direct alpha counting techniques, or are analyzed for uranium content using standard fluorometric methods. Results are reported in units of gross alpha activity or milligrams of natural uranium per volume of air.

The frequency of air sampling varies widely throughout the milling industry, but generally samples are obtained or filters are changed on a monthly or weekly basis. More frequent sampling may be required in high dust zones of the mill crushing area.

\subsubsection{Sampling for Radon and Radon Daughters}

Radon and its daughter products are generated by the radioactive decay of ${ }^{226} \mathrm{Ra}$, and are therefore found wherever radium is present. Radon, being a noble gas, migrates into the air and is transported by air streams away from the source. Ventilation is a primary method of reducing radon concentrations in the workplace.

Radon is limited to $30 \mathrm{pCi} / \mathrm{l}\left(3 \times 10^{-8} \mu \mathrm{Ci} / \mathrm{m} \ell\right)$ in air by $10 \mathrm{CFR}$, Part 20, and radon daughters are correspondingly limited to $0.3 \mathrm{WL}$. (a) Air sampling for radon and daughters is generally performed on a routine basis; however, the measured concentrations rarely exceed the established occupational limits. These materials concentrate in closed-in areas, and monitoring can indicate when increased ventilation is needed.

A number of different techniques have been developed for direct measurement of radon (Table 2). Since radon concentrations may vary by an order of magnitude over short periods of time, many grab samples or continuous radon monitoring are usually required to establish the average annual levels. Single measurements may provide a faulty indication of annual average, maximum, or minimum levels at a particular location.

(a) Working Level - A working level is equivalent to any combination of radon daughters in one liter of air which will result in the emission of $1.3 \times 10^{5} \mathrm{MeV}$ of alpha energy in the complete decay through ${ }^{214} \mathrm{Po}$. This potential alpha energy will occur when $100 \mathrm{pCi} / \ell$ of ${ }^{222} \mathrm{Rn}$ in air is in equilibrium with its daughter products. 
The dose to workers from inhalation of radon and daughter products is due primarily to deposition of radon daughters in the airways of the respiratory tract. Several methods are available for measuring radon daughter concentrations in air (Table 3 ). Radon daughter concentrations are reported in units of working level (WL) or working level hours(WL-hr). One working level month (WLM) is the equivalent of $170 \mathrm{WL}-\mathrm{hr}$. A state-of-the-art discussion on the methods that can be used to survey the mill and surrounding areas for radon and radon daughters is published elsewhere (Atomic Industrial Forum 1977).

\subsubsection{Sampling for Airborne Yellowcake Dust}

Air sampling for suspended uranium aerosols is of great importance in the yellowcake precipitation, drying, and packaging areas of the mill. Continuous monitoring of the air in breathing zones should be performed by fixed-location air sampling equipment. In addition, lapel samplers may be worn by workers to better determine the level of uranium in the breathing atmosphere. The $10 \mathrm{CFR}$, Part 20 limit for airborne yellowcake dust is $0.2 \mathrm{mg}$ uranium $/ \mathrm{m}^{3}$ air.

The mill process and equipment used have much influence on the levels of yellowcake dust generated. Dry processes tend to produce much greater levels of dust. Newer equipment is designed to reduce the amount of dust released into the air or up the stack. Bag filters collect dust and return it to the process. In addition, the biological hazard of yellowcake is strongly dependent upon its solubility characteristics. It is likely that regulatory agencies will require future tests of yellowcake dust solubility to aid in the interpretation of airborne uranium measurements.

\subsubsection{Gamma Radiation Monitoring}

The major portion of the above-background external gamma radiation is attributable to ${ }^{226} \mathrm{Ra}$. In most uranium ores, radium is found in secular equilibrium with the uranium decay series. In concentrating uranium at the mill, radium is separated from the product and is discarded as part of the mill tailings. Quantities of radium in processed uranium are small. 
TABLE 2. Selected Methods for Determining Radon Concentrations in Air

\begin{tabular}{|c|c|c|c|}
\hline Method & Application & Sensitivity & Comments \\
\hline $\begin{array}{l}\text { Lucas cell scintilla- } \\
\text { tion flask }\end{array}$ & Grab or continuous & $<0.1 \mathrm{pCi} / \mathrm{l}$ & \multirow[t]{3}{*}{$\begin{array}{l}\text { Inexpensive, gen- } \\
\text { erally reliable }\end{array}$} \\
\hline $\begin{array}{l}\text { Two filter, delayed } \\
\text { counting }\end{array}$ & Grab or continuous & $<0.1 \mathrm{pCi} / \mathrm{l}$ & \\
\hline $\begin{array}{l}\text { Air collection and } \\
\text { counting }\end{array}$ & Grab or continuous & $0.05 \mathrm{pCi} / \ell$ & \\
\hline $\begin{array}{l}\text { Passive inverted funnel } \\
\text { with TLD chips }\end{array}$ & Continuous & $0.05 \mathrm{pCi} / \mathrm{l}$ & \multirow{2}{*}{$\begin{array}{l}\text { Quiet, effective } \\
\text { for integration, } \\
\text { inexpensive }\end{array}$} \\
\hline $\begin{array}{l}\text { Activated charcoal } \\
\text { collections }\end{array}$ & Continuous & $0.01 \mathrm{pCi} / \ell$ & \\
\hline Track etch dosimeters & Continuous & $100 \mathrm{pCi} / \mathrm{l}$ & $\begin{array}{l}\text { Inexpensive, } \\
\text { track counting } \\
\text { required }\end{array}$ \\
\hline
\end{tabular}

TABLE 3. Selected Methods for Determining Radon Daughter Concentrations in Air

\begin{tabular}{|c|c|c|c|}
\hline Method & Application & Sensitivity & Comments \\
\hline $\begin{array}{l}\text { Kusnetz and Tsivoglou } \\
\text { filters }\end{array}$ & Grab sampling & $0.0005 \mathrm{WL}$ & $\begin{array}{l}\text { Commonly used, } \\
\text { simple, and } \\
\text { inexpensive }\end{array}$ \\
\hline Modified Kusnetz method & Grab sampling & $0.0005 \mathrm{WL}$ & $\begin{array}{l}\text { Integration } \\
\text { device or alpha } \\
\text { spectrometer } \\
\text { required }\end{array}$ \\
\hline $\begin{array}{l}\text { Integrating pump } \\
\text { sampler with TLD } \\
\text { detector }\end{array}$ & Continuous & $1 \mathrm{WL}-\mathrm{hr}$ & $\begin{array}{l}\text { Noise, requires } \\
120 \text { VAC power }\end{array}$ \\
\hline Alpha track etch film & Continuous & $5 \mathrm{WL}-\mathrm{hr}$ & $\begin{array}{l}\text { Inexpensive, but } \\
\text { track counting } \\
\text { required }\end{array}$ \\
\hline $\begin{array}{l}\text { Instant working level } \\
\text { meter }\end{array}$ & Grab sampling & $0.01 \mathrm{WL}$ & $\begin{array}{l}\text { Portable, quick, } \\
\text { expensive, easy } \\
\text { to use }\end{array}$ \\
\hline
\end{tabular}


Area monitoring for external radiation is performed with calibrated portable survey instruments such as the Geiger-Mueller (G-M) counters, scintillation counters (Micro R-Meter), or equivalent. G-M counters are sensitive to detection levels as low as about $0.02 \mathrm{mR} / \mathrm{hr}$, and scintillation detectors are reasonably accurate at the $0.003 \mathrm{mR} / \mathrm{hr}$ level.

Technicians should perform gamma radiation surveys throughout the mill at least once per month. External survey results within a mill may range from 0.02 to $0.5 \mathrm{mR} / \mathrm{hr}$. Higher radiation levels ( 1 to $3 \mathrm{mR} / \mathrm{hr}$ ) may be detected in the yellowcake drying and packaging areas, above some of the ore storage piles, and in the vicinity of tailings ponds. Radium also tends to accumulate in piping (especially elbows), where it is easy to detect but difficult to remove. Mill personnel should take survey readings prior to any maintenance operations.

Some facilities continuously monitor external radiation levels using thermoluminescent dosimeter chips (TLDs) or film dosimeters placed throughout the process areas. The dosimeters are exchanged monthly or quarterly by service contractors and evaluated.

Results of all surveys must be recorded and maintained for a period of at least two years. Failure to do so, or failure to retain adequate records of such surveys constitutes a violation of state or federal regulations. Regular calibration of survey instruments and periodic auditing of survey data by management personnel are also required by the licensing authority.

\subsubsection{Contamination Control Surveys}

Surface contamination surveys should be conducted periodically in all areas where external contamination is possible. The contamination of surfaces may give rise to unwanted inhalation or ingestion of small quantities of uranium. It may also interfere with laboratory measurements. Area monitoring is also commonly performed in change rooms, administrative office areas, maintenance shops, and analytical laboratories.

Often, the presence of uranium contamination (especially yellowcake) is detected by visual observation. In circumstances where the activity is not readily observed, the quantity and activity of the material present may be 
determined with alpha-beta survey instruments and filter-smear sampling. Sampling should be performed regularly or whenever there is a need for special surface monitoring.

A carefully planned program of facility monitoring can provide important information about the temporal changes in occupational radiation environment, and indicate the direction of trends that may require corrective action. In this way, facility monitoring can contribute greatly to worker protection. Table 4 shows suggested mill locations for surveillance activities.

\subsection{EXPOSURE CONTROL IN URANIUM MILLS}

During the first years of uranium processing, it was generally assumed that exposure of workers to uranium dust, radon, or radon daughters would not lead to harmful health effects. However, more recent epidemiological investigations, improved internal dosimetry, and more stringent regulatory control have resulted in increased awareness. regarding the health protection of workers. Airborne concentrations of uranium ore dust, yellowcake dust, radon daughters, and uranium compounds, and exposures to external gamma radiation have been considerably reduced from levels experienced in previous years. This section discusses methods that can and should be implemented at uranium mills to maintain radiation exposures to levels that are as low as can reasonably be achieved utilizing current technology.

The control of radiation exposures is required by the Code of Federal Regulations, and the content of a plant's personnel protection program must be approved by the licensing authority. The required margin of radiological safety and the control of occupational radiation exposures may be accomplished through optimal use of process-related safety systems, basic engineering design, respiratory protection programs, the use of other protective clothing, and employee training and review programs. These elements are further discussed below.

\subsubsection{Process Safety Engineering}

Containment dependability, dust collection, and indoor area ventilation are the primary design features that prevent airborne radioactive materials from reaching unacceptable levels, and keep chemical spills or other liquid 

TABLE 4. Suggested Facility Monitpring Locations in Mills

Work Area

Type of Monitoring Required $(b)$

Coarse ore storage

G

R

$\mathrm{U}$

Primary rock crusher

G

R

$\mathrm{U}$

Fine ore bins

G

$\mathbf{R}$

$\mathrm{U}$

Ball or rod mill

G

R

$\mathrm{U}$

Ore conveyor system

G

R

$\mathrm{U}$

Leach tanks

G

R

CCD settling tanks

G

R

Solvent exchange

G

R

Precipitation circuit

G

R

$\mathrm{U}$

Yellowcake dryer

G

R

$\mathrm{U}$

Yellowcake packager

G

R

$\mathrm{U}$

Laboratories

G

R

C

Change rooms

G

R

C

Lunchroom

G

R

C

Administrative offices

G

$\mathbf{R}$

C

Maintenance shops

G

R

C

(a) To determine occupational exposure to radioactivity. Does not include monitoring required for environmental assessments, nor monitoring of nonradiological chemical hazards.

(b) Code:

$\overline{\mathrm{G}}=$ external gamma radiation survey

$\mathrm{R}=$ air sampling for radon daughters

$\mathrm{U}=$ air sampling for uranium aerosols

$\mathrm{C}=$ surface contamination surveys 
releases from entering noncontained areas of the uranium mill. The incorporation of safety engineering practices has increased with the construction of newer facilities, but many problems still exist at older facilities. In most instances, the production equipment is designed to handle dispersible uranium in a contained system. However, maintenance procedures are frequently required, and failure of mechanical equipment provides opportunities for breach of containment. Each facility should be reviewed to see if the engineering is adequate to insure that exposures are as low as possible. Needed changes should be implemented.

Ventilation systems have been added to older plants to reduce indoor dust levels. Ventilation is particularly important in maintaining radon and radon daughter levels within recommended limits.

Mills should utilize the following design and process safety systems which help control occupational exposures:

- ventilation-dust collection system in the crusher building,

- dust collection system located over the fine ore storage bins,

- ventilation-dust collection system in the sample preparation room,

- leach tank exhaust system,

- ventilation systems for the solvent extraction or ion exchange areas,

- ventilation system in the yellowcake precipitation area, and

- ventilation-dust collection system in the yellowcake drying and packaging area.

One mill is planning to implement an entirely wet yellowcake production process to reduce the potential for inhalation of radioactive materials. The process would include wet crushing of the ore and shipment of the final yellowcake product as a slurry to the conversion facility.

\subsubsection{Respiratory Protection}

Although uranium dusts are only mildly radioactive, the radiotoxicological effects of chronic inhalation of uranium are still not well known. Since the 
chemical toxicity of uranium compounds taken into the body may be greater than the radiological toxicity, it is prudent to provide a measure of respiratory protection for the uranium worker. Inhalation represents the primary pathway for intake of radioactive materials and other hazardous nonradioactive chemicals by workers in uranium mills. Most of the exposure can be prevented by following a suitable respiratory protection program supervised and enforced by management.

In those areas of the plant where controls are insufficient to maintain general air uranium concentrations consistently below allowable limits as given in 10 CFR 20 Appendix B, and during hazardous maintenance operations, the use of respirator masks is advised. However, respirator use should not be substituted for proper design and operation of process equipment. Optimum equipment design and routine maintenance of machinery should make the use of respirators unnecessary. However, this is rarely the situation.

Respirators should be worn all or part of the time in the following areas:

- crushing - particularly when low moisture ores are being crushed which result in high airborne dust concentration.

- yellowcake drying and packaging area - most mills require workers to wear respirators at all times in these areas.

- maintenance operations - particularly in the yellowcake drying and packaging areas.

Respirators should be readily available for use when needed. For adequate protection, respirators should be properly fitted to the face. The safety training program should include instructions on the care, storage, and fitting of respiratory devices. Guidance for the appropriate use of respirators is specified in Title 29 Code of Federal Regulations Part 1910.134, ANSI Standard Z88.2 (ANSI 1969), U.S. Nuclear Regulatory Commission Guide 8.15 (USNRC 1976a), and NUREG-0041 (USNRC 1976b).

\subsubsection{Contamination Control and Protective Clothing}

The purpose of contamination control is to limit the quantities of radioactive materials that may at some time enter the body through ingestion or inhalation. Dust control methods were previously mentioned. Inevitably, 
however, tools and machinery, floors, worker's clothing and shoes, and other surfaces near the process equipment become contaminated with small amounts of radioactivity--especially in the yellowcake precipitation, drying, and packaging areas. These areas need to be hosed down with water at regular intervals to recover the product and prevent the uranium from becoming airborne. The objective of contamination control is to prevent the spread of radioactivity from the process area to administrative offices, lunchrooms, laboratories, or contamination of street clothing and items taken from the mill for repair or disposal.

Overalls or other work clothing must be provided and laundered by the plant daily. Change rooms with lockers should be located in a buffer zone between the process and administration areas. The worker should be required to wear clothing and boots supplied by the company, and to change and shower before leaving at the end of the work shift. Where necessary, workers should be instructed to change clothing and scrub hands, arms, and face thoroughly before going to lunch. Obviously those workers in process areas where contamination is not a possibility would not be required to take the same precautions as workers in areas of the plant with frequent contact with uranium compounds.

Monitoring for area contamination was discussed in Section 4.2.3. Contamination of less than $4 \mathrm{pCi} / \mathrm{cm}^{2}\left(10 \mathrm{dpm} / \mathrm{cm}^{2}\right)$ indicates good housekeeping and a successful contamination control program. Review of contamination monitoring records should be used to detect unfavorable trends.

\subsection{TRAINING}

Training develops an employee's versatility and should foster a greater interest in his work. Adequate training also leads to improved safety and fewer opportunities for error.

Uranium mill facilities are required by the licensing authority to provide a radiological protection training program for all employees who will work with or around radioactive materials. New employee orientation should begin before the worker is assigned to hazardous responsibilities. Periodic testing of the employee's knowledge and skills, and continuing on-the-job training are 
also required. The facility must issue a description of the training program (including copies of radiological safety instructions given to each employee) when submitting application for an operating license. The following items must be included:

- personal hygiene, including on-site washing and showering,

- surveying for contamination prior to eating or leaving the plant,

- instructions for wearing personnel monitoring devices and respirators,

- instructions for good housekeeping and contamination control.

Since the laborer is probably unfamiliar with the nature of ionizing radiation, the basic training program should also include:

- general health effects of routine occupational exposure to radioactive materials, overexposures, and chronic exposure to these materials

- emergency procedures

- purpose and use of protective clothing

- a description of the company's medical program

- the importance of following instructions and workplace rules.

In the early history of uranium milling operations and uranium processing, formal training programs were not instituted. Training, if any, came with experience. At some mills, an AEC information booklet on radiation effects was distributed to each employee. This situation no longer exists. All uranium mills have now instituted training programs. Some, for example, now give 24 class-hours of new employee indoctrination with follow-up 8 class-hour refresher courses (with exams) annually. Each company selects the training program format suited to its own specific needs. The training program is then approved by the regulatory agency.

The existence of a training program cannot guarantee that the instructions will be learned or followed. Each type of facility may have "problem employees" who have undesirable personal hygiene traits and who may casually disregard radiological safety rules. Reprimands from safety directors and even job termination for these reasons are not uncommon in the industry. 


\subsection{RECORDKEEPING}

Title 10, Code of Federal Regulations Part 20.401 requires each licensed uranium facility to maintain careful records showing radiation exposures of all individuals for whom personnel monitoring is required. Also, the facilities must maintain results of radiation surveys, monitoring, and dispositions of radioactive materials. This includes bioassay results. Records must be prepared according to recommendations of the American National Standards Institute (ANSI N13.6, Practice for Occupational Radiation Exposure Records Systems, 1966), and must be kept on file for a minimum of two years. Facilities should, however, maintain these records indefinitely.

The licenced facility must immediately report to the regulatory agency any loss, theft, or accidental release of radioactive materials. In addition, any overexposures, or conditions that could expose individuals to radiation levels in excess of maximum permissible limits must be reported immediately. The facility must also file a worker termination report to the regulator which summarizes the individual's radiation exposure history for the period of employment. Records and files are inspected annually by the regulatory agency for compliance to 10 CFR Part 20 . 


\subsection{EXPOSURE EVALUATION}

Uranium mills are required to determine the extent of any worker's exposure to radioactive materials (10 CFR Part 20). The dose from these materials when taken into the body cannot be adequately determined by personnel dosimeters or facility air monitoring equipment alone. Air monitoring may provide the initial indication that an overexposure may have occurred. However, breathing rates, use of respirators, proper operation of protective equipment, and ventilation rates may influence the amount of material deposited in the lungs. Time-weighted air monitoring is insufficient for determining internal doses to workers.

Internal exposures can be estimated using bioassay techniques. Bioassay is the measurement of radiation emitted from the body using chest or wholebody counting equipment, or the measurement of radioactive materials in biological samples taken from the body (blood, hair, urine, and feces). Urinalysis is the primary type of bioassay required of uranium mills.

It is important for mills to have the capability of determining worker exposures to uranium. Uranium exhibits both radiological and chemical toxicity, and the objective of an adequate health and safety program is to protect the worker from both effects. The retention, metabolism, and ultimate degree of toxicity of uranium and its associated decay series products depend upon the chemical forms and specific activities of these elements. The chemistry of uranium determines its solubility in body fluids, and hence its retention time in body tissues. Although the specific activity of natural uranium is extremely low ( 1.5 alpha disintegrations $/ m i n-\mu g)$, insoluble forms of uranium may remain in the body for long periods of time and accumulate during periods of chronic exposure. On the other hand, soluble uranium compounds leave the body more rapidly and may damage kidney cells. The following is a classification scheme for solubilities of uranium compounds in the lung:

- Class D - soluble (transportable) compounds with a solubility halftime (time for half of the compounds to be dissolved in lung fluids) of $<1$ to 10 days. 
- Class W - moderately soluble (slowly-transportable) compounds with an estimated solubility half-time of $>10$ to 100 days inclusive.

- Class Y - relatively insoluble (very slowly-transportable) compounds with an estimated solubility half-time of $>100$ days.

As part of their internal dosimetry assessment program, uranium mills should determine the solubility classification for all sources of respirable radioactive materials potentially affecting the worker.

\subsection{BIOASSAY}

Bioassay may be a "direct" or "indirect" method for assessing intakes of radioactive materials by workers. The major direct method is lung counting. Indirect methods include measurement of the radioactivity content of excreta (urine and feces), blood, or breath samples. A urine sample, for example, provides an indication of the amount of radioactive material that has left the body. To determine body burdens from urinalysis results, one must turn to accepted biological excretion models and back-calculate the body burden that would result in the observed excretion.

Bioassay has become an important aspect of radiation protection in the uranium industry. Urinalysis can provide early indication of whether a worker has inhaled or ingested a significant quantity of uranium. The results can provide guidance for the type of corrective action that should be taken as a consequence of a suspected overexposure. Bioassay at uranium mills is required:

- to assist the facility in establishing a baseline excretion value for a new employee, or to detect any pre-existing body burdens that may have been received prior to employment

- to assist in the estimation of uranium intake by inhalation or ingestion, and to indicate levels warranting corrective or remedial action

- to verify the consistency and reliability of the air monitoring program, and to watch for the development of unfavorable trends 
- to verify other forms of exposure control such as improvements made in process equipment or radiation safety procedures

- to follow up in the event that a worker has been removed from his duties because of unacceptably high bioassay results, and to indicate the time at which bioassay levels have again become acceptable so that work restrictions may be removed (USAEC 1974).

Regulatory Guide 8.22, Bioassay at Uranium Mills (USNRC 1978) is the primary guidance on bioassay programs at mills today. It indicates that routine bioassays should be performed on workers routinely exposed to airborne yellowcake and/or airborne uranium ore dust. In addition, Regulatory Guide 8.22 suggests that bioassays should be performed on any worker suspected of an exposure to yellowcake in excess of $4 \times 10^{-9} \mu \mathrm{Ci}-\mathrm{hr} / \mathrm{m} \ell$ (air) during a period of one work-week or to uranium ore dust in excess of $5.2 \mathrm{x}$ $10^{-8} \mu \mathrm{Ci}-\mathrm{hr} / \mathrm{m} \ell$ (air) during a period of one calendar quarter.

Some questions still remain as to whether bioassay programs, costly and time consuming as they are, may in fact be considered as adequate methods of monitoring employee exposure to uranium. Because of the current controversy surrounding the bioassay requirements as they now stand, a new regulatory guide is being prepared and the Nuclear Regulatory Commission is expanding its internal review of the urinalysis requirements. It is expected that bioassay will remain a requirement for uranium facilities, considering the justifications previously listed. Major improvements should be expected in the analytical methods and procedures used for determining the uranium content of urine samples.

\subsubsection{Methods of Bioassay}

Guidance for conducting a bioassay program is available from the NRC in Regulatory Guide 8.9 Acceptable Concepts, Models, Equations, and Assumptions for a Bioassay Program (USAEC 1973), 8.11 Applications of Bioassay for Uranium (USAEC 1974), 8.22 Bioassay at Uranium Mills (USNRC 1978), and from the document WASH-1251 Applications of Bioassay for Uranium (USAEC 1975), which provides technical justification for Regulatory Guide 8.11 of the same title. 


\subsubsection{Urinalysis}

A minimum bioassay program may be instituted if the quarterly air sampling shows that the average airborne uranium concentration in the worker's breathing zone does not exceed 10 percent of the appropriate Derived Air Concentration (DAC) given in Appendix B of $10 \mathrm{CFR}$, Part 20, and if the maximum result obtained to calculate the average does not exceed 25 percent of the DAC. The minimum bioassay program consists of an annual or semiannual urine sampling of all workers, and a more frequent sampling protocol for those who may be exposed to higher-than-average uranium concentrations.

Regulatory Guide 8.22 indicates that urine samples should be collected at least every two weeks from potentially exposed mill workers. Analytical techniques for determining uranium concentrations in the urine should have a minimum sensitivity of $5 \mu \mathrm{g} / \ell$.

In some cases, the mill may be able to demonstrate that airborne uranium concentrations are sufficiently low and air monitoring systems sufficiently adequate to make urinalysis unnecessary or less frequent than the two-week time interval suggested in Regulatory Guide 8.22. Strict adherence to regulatory guides requires a formal urinalysis program to be implemented wherever air sampling is required for purposes of occupational exposure control. Currently, there is a wide variation in the frequency of urinalysis for workers among mills. Of the several mills visited the following programs were observed:

- biweekly urinalysis on crushers and yellowcake workers

- biweekly urinalysis on all mill workers, or

- annual urinalysis on all mill workers.

Frequency of urinalysis is an important consideration. If delayed, soluble uranium compounds may be excreted and inflict damage to kidneys before sample collections are made. It is recommended in Regulatory Guide 8.22 that specimens should be collected every two weeks. Urine specimens are normally collected when the worker returns to the mill following normal work interruption of from two to four days (but not longer than four days). This delay allows the worker to shower and remove external contamination from his body before providing a sample. Delays beyond four days are undesirable because 
uranium may be excreted during the delay and thus go undetected when the sample is taken. To prevent contamination of the sample, the worker's hands should be clean, and the sample should be retrieved before the worker has changed into work clothing or entered contaminated areas of the mill. The system for establishing a collection frequency is outlined in Regulatory Guide 8.11. With higher airborne uranium concentrations, urinalysis must be performed more frequently.

Laboratory methods for determining uranium concentrations in the urine are optional with the facility and are not specified in the regulatory guides. Ultraviolet fluorometry is most often the method of choice. This procedure is described in further detail in HASL Procedure Manual 300 (Harley 1972). Control specimens should be obtained from persons known to have no body burden of uranium other than that which one normally expects from the natural environment. To monitor the quality of the analysis from day to day, certain control specimens should also be spiked with known uranium to give a known concentration of $15 \mu \mathrm{g} / \ell$ and $30 \mu \mathrm{g} / \ell$. The minimum detectable amount for the measurement technique should be $5 \mu \mathrm{g} / \ell$ uranium or less.

\subsubsection{In-Vivo Counting}

A standard method for determining intake of uranium is chest counting. However, this capability is beyond the current resources of most uranium mills. Chest counting services are available, however, from specialized subcontractors, one of which is equipped with mobile whole-body or chest counting laboratories. The in-vivo measurement for internally deposited uranium is performed using sodium iodide (thallium activated) solid crystal or phoswich detectors and a multichannel analyzer. Since the alpha emissions of ${ }^{238} \mathrm{U}$ do not penetrate the chest wall, the measurements of uranium in the lungs is based upon detection of either the $186 \mathrm{keV}$ photon from ${ }^{235} \mathrm{U}$ or the two photons from ${ }^{234} \mathrm{Th}$ at $63 \mathrm{keV}$ and $93 \mathrm{keV}$.

Most uranium mill facilities have problems with high natural background rates. Mobile laboratories that service these facilities carry some shielding against background radiation. For quality results, it is recommended that chest counting be performed at institutions (national laboratories and some universities) with fixed equipment, graded shielding, and highly qualified 
personnel capable of measuring and interpreting the results. For detection equipment, phoswich detectors with computer-based multichannel analyzers are generally regarded as the most efficient systems for lung counting.

Since special expertise, equipment, and facilities are required to perform chest counting, it has not been feasible to require uranium mills to establish individual capabilities. A number of facilities do, however, contract for these services from independent sources.

Regulatory Guide 8.22 suggests that in-vivo measurements (lung counting) be performed annually using equipment capable of measuring $9 \mathrm{nCi}$ or less uranium in the lung.

\subsubsection{Action Based on Bioassay Results}

Regulatory Guide 8.22 provides guidance for action by mill management based on results of bioassay measurements. Tables 5 and 6 show corrective action for urinalysis and lung counting results, respectively.

\subsection{ASSESSMENT OF EXTERNAL GAMMA EXPOSURES}

Two fundamental methods were described earlier for determining occupational exposures to penetrating gamma radiation: 1) personnel dosimeters and 2) calculation from external survey results and a record of time spent by each worker in the particular working area. Currently, most personnel dosimeters are read monthly or quarterly by service contractors. Monthly exposure results generally range from 0 to $40 \mathrm{mR}$, with very few (if any) in excess of 25 percent of the maximum permissible occupational limit of $5 \mathrm{rem} / \mathrm{yr}$. Some uranium mills have discontinued the use of personnel dosimeters after one or two years of monitoring experience. While some facilities badge all employees in the mill, other facilities limit dosimeter use to yellowcake workers, crusher operators, sample-takers, and laboratory personnel. 


\section{TABLE 5. Corrective Actions Based on Urinary Uranium Concentration Results}

(U.S. NRC 1978)

Urinary Uranium Concentration

Less than $15 \mu \mathrm{g} / \mathrm{\ell}$

15 to $30 \mu \mathrm{g} / \mathrm{\ell}$

Greater than $30 \mu \mathrm{g} / \mathrm{l}$

Greater than $30 \mu \mathrm{g} / \mathrm{l}$ for four consecutive specimens or greater than $130 \mu \mathrm{g} / \mathrm{l}$ for any specimen

\section{Interpretation}

Uranium confinement and air sampling capabilities are adequate.

Uranium confinement and perhaps air sampling capabilities do not provide an adequate margin of safety.

Uranium confinement and perhaps air samplin $\beta_{a}$ capabilities are not acceptable.

Possibility of kidney damage to worker.
Actions

None

1. Confirm results (repeat urinalysis).

2. Determine why air samples were not representative and did not warn of excessive concentrations of airborne uranium. Make corrections.

3. Identify the cause of airborne uranium and initiate additional control measures.

4. Determine whether other workers could have been exposed and perform bioassay measurements for them.

5. Consider work assignment limitations to ensure the worker does not exceed urinary uranium concentration of $30 \mu \mathrm{g} / \mathrm{l}$.

1. Take the actions given above for 15 to $30 \mu \mathrm{g} / \mathrm{\ell}$.

2. Continue operations only if it is virtually certain that no other worker will exceed a urinary uranium concentration of $30 \mu \mathrm{g} / \ell$.

1. Take the actions given above.

2. Have additional urine specimen tested for albuminuria.

(a) Unless the result was anticipated and caused by conditions already corrected. 
TABLE 6. Corrective Actions Based on In-Vivo Results (from Regulatory Guide 8.22, U.S. NRC 1978)

Amount of Uranium Detected

Below $9 \mathrm{nCi}$ of uranium

9 to $16 \mathrm{nCi}$

जि

\section{Interpretation}

This result does not necesssarily indicate that uranium confinement and air sampling capabilities are confined.

Confinement and aix sampling capabilities un reliable. Uranium activity in lungs undesirably high.

Confinement and air sampling not acceptable.
Actions

Rely on urinalysis results to determine corrective actions.

1. Confirm results (repeat urinalysis).

2. Determine why air samples were not representative and did not warn of excessive concentrations of airborne uranium. Make corrections.

3. Identify the cause of airborne uranium and initiate additional control measures.

4. Determine whether other workers could have been exposed and perform bioassay measurements for them.

5. Consider work assignment limitations that will permit the lung burden to be reduced through natural elimination; ensure that the lung burden does not exceed $16 \mathrm{nCi}$.

1. Take the actions given above for 9 to $16 \mathrm{nCi}$.

2. Establish work restrictions for affected workers. (Normally, workers with a lung burden greater than $16 \mathrm{nCi}$ are not allowed by their employer to resume work in airborne activity areas until the burden is reduced to less than $9 \mathrm{nCi}$.)

3. Perform individual case studies (bioassays) for affected workers

4. Continue operations only when it is certain no additional workers will exceed $16 \mathrm{nCi}$.

(a) Unless the result was anticipated and caused by conditions already corrected. 


\subsection{REGULATION OF URANIUM MILLS}

Uranium mills were licensed and regulated by the AEC or by agreement states until 1974, when the Energy Reorganization Act of 1974 transferred this responsibility to the Nuclear Regulatory Commission (NRC) or agreement states. (a) The NRC retains the authority to regulate uranium mills in nonagreement states. Licensing requirements in agreement states must be no less stringent than those in NRC-licensed nonagreement states. Another regulatory agency that has jurisdiction over uranium mills is the Mining Safety and Health Administration (MSHA), which has authority to enforce radiation and safety standards.

The licensing of uranium mills is governed by the Atomic Energy Act of 1954 (amended). In nonagreement states, uranium mills that process or refine ores containing 0.05 percent or more of uranium by weight are required to have an NRC source material license. An application for such a license should be in accordance with the requirements of $10 \mathrm{CFR} 40$, "Licensing of Source Material." General guidance on the format and content of the license application is provided by NRC Regulatory Guide 3.5 (USNRC 1977). In agreement states, a similar application must be presented to the appropriate state regulatory agency.

The license application serves as the principal technical communication between the applicant and the NRC. Each applicant must demonstrate in the application that the design of the facility, together with proposed operating procedures, will ensure the degree of safety required by regulations. While all applicants are licensed by $\mathrm{NRC}$, different processes may require different measures being applied to protect workers. (Regulatory aspects dealing with environmental issues are beyond the scope of this report.)

(a) An agreement state refers to any state with which the regulatory agency has entered into an agreement under Section 274b of the Atomic Energy Act of 1954 (as amended) to conduct the licensing and regulation of facilities within that state. The first such agreement was initiated in 1962. Colorado, Florida, Louisiana, New Mexico, Texas, and Washington are agreement states that have milling operations today. 
Part of the regulatory procedure includes semiannual inspections of licensed mills by NRC inspectors (or by state inspectors in agreement states). These inspections, along with periodic renewal of a mill's source material license, are used by regulators to verify that mills are complying with the conditions specified in the license.

Mils must comply with the radiation protection standards found in 10 CFR 20, "Standards for Protection Against Radiation." Initially written in January 1957 and updated annually, 10 CFR 20 has undergone over one hundred changes. In 1970, the AEC began issuing safety guides (now called regulatory guides) to assist applicants and licensees in complying with the general requirements of the Code of Federal Regulations. Regulatory guides reflect the current NRC staff position for licensing facilities. Thus, the practices described within such guides are used as a basis for evaluation of license applications. Compliance with the regulatory guides themselves is not required; individual applicants or licensees may propose alternatives for new or existing programs that are not necessarily consistent with the guides. The justification for such alternatives is reviewed by the NRC staff and evaluated on a case-by-case basis. 


\subsection{SURVEY OF CURRENT PRACTICES}

Questionnaires were sent to all operating conventional and unconventional uranium milling facilities in the United States during the period JuneSeptember 1981. The survey included questions about production and employment levels, process descriptions, methods of facility monitoring, and exposure evaluation data. Questions were written in simple, multiple-choice format. Responses were received from most of the facilities contacted, as summarized in Table 7 below.

TABLE 7. Summary of Questionnaire Response

\begin{tabular}{|c|c|c|c|}
\hline Type of Facility & $\begin{array}{c}\text { Number } \\
\text { Sent }\end{array}$ & $\begin{array}{r}\text { Number } \\
\text { Received }\end{array}$ & Percent \\
\hline Conventional mills & 21 & 14 & 67 \\
\hline Byproduct recovery & 5 & 4 & 80 \\
\hline Solution mines & 9 & 8 & 89 \\
\hline Heap-leaching sites & 3 & 1 & 33 \\
\hline Total & 38 & 27 & 71 \\
\hline
\end{tabular}

\subsection{CONVENTIONAL MILLS}

Production and employment information obtained from 14 conventional uranium mills is given in Table 8. The identity of the facilities is not given to respect rights of confidentiality. Some of the questions were considered proprietary, and the requested information was not provided by the company.

Two categories of workers with greatest potential for inhalation of airborne radioactive materials are the crusher area workers, and the yellowcake drying/packaging workers. Each group constituted about 6 percent of the total mill work force.

The survey indicated strong preference for production of insoluble, high-fired yellowcake product. Seventy percent of the mills reported use of drying temperatures above $500^{\circ} \mathrm{C}$. The remaining mills reported a variety of lower-temperature drying processes. 
TABLE 8. Conventional Mills Production and Employment Data

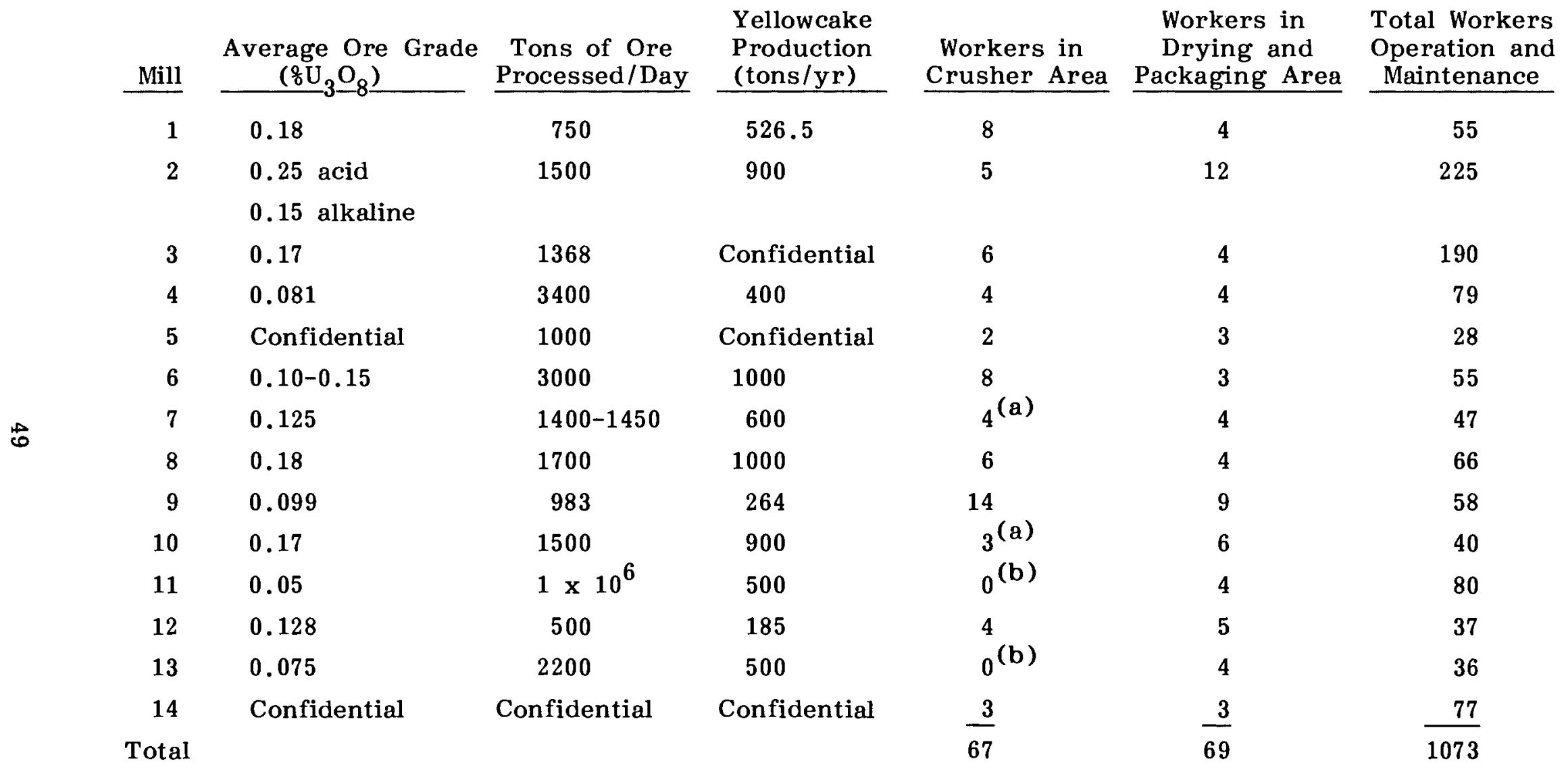

(a) Wet grinding.

(b) No crushing area. 
All facilities sample for airborne uranium in the ore crushing areas. The most common method is monthly air-filter grab sampling.

All facilities sample air for uranium in the drying and packaging area. Sixty-four percent perform weekly grab sample measurements; 14 percent conducted continuous air monitoring.

Only a single facility reported no sampling for radon daughters in the ore crushing section. Among those facilities that do conduct radon daughter measurements, sampling frequencies vary from weekly to quarterly. Over 90 percent employ the Kusnetz method for determining radon daugther concentrations.

All facilities measure external gamma radiation levels in and around the process areas. Portable gamma survey instruments and fixed-location TI.D monitors are commonly used. Measurements are performed monthly (50 percent) or quarterly ( 50 percent).

Eighty percent of the mills conduct urinalysis of all workers. The remaining mills conduct urinalysis only on workers with increased potential for exposure, such as precipitation, drying, and packaging workers, and maintenance workers. The frequency of bioassay varies from biweekly to annually. At 20 percent of the mills contacted, the sampling frequency is related to job category; yellowcake workers are sampled biweekly whereas crushermen are sampled on an annual basis. All mills reported that their average urinalysis result is less than $8 \mu \mathrm{g}$ uranium per liter urine.

Chest counting is performed routinely at 64 percent of the mills in the survey. Chest counting is performed only for special situations at 14 percent of the sites, while the remainder (22 percent) have never conducted chest counting of employees.

Eighty-six percent of mills in the survey reported requiring all workers to wear personnel external gamma dosimeters. Fourteen percent require dosimeters for a limited number of potentially exposed workers. TLD badges are used at 86 percent of the facilities, and film badge dosimeters are employed at the remaining 14 percent. Dosimeters are evaluated either monthly (64 percent) or quarterly (36 percent). One site reported biweekly dosimeter evaluations for pregnant female workers. 
All mills reported mandatory use of respirators by yellowcake drying and packaging operators. Fifty percent require respirators during maintenance activities and only 21 percent require crushermen to wear respirators.

\subsection{SOLUTION MINING/YELLOWCAKE PRODUCTION PROCESSES}

Production and employment data for eight of the currently operating solution mining operations are presented in Table 9. Four of these facilities ship uranium as a slurry rather than a powder and therefore require no workers in the yellowcake drying and packaging area. Yellowcake drying and packaging workers at the other solution mines represent about 7 percent of the total workforce.

Three out of four of the solution mines that ship their product as powder have product drying temperatures in excess of $500^{\circ} \mathrm{C}$. Half of these facilities conduct continuous air monitoring in the vicinity of drying and packaging operations. The remainder perform weekly or quarterly air filter grab sampling.

TABLE 9. Solution Mining Production and Employment Data

\begin{tabular}{|c|c|c|c|c|}
\hline Operation & $\begin{array}{l}\text { Ore Grade in } \\
\text { Mine Field } \\
\quad\left(\frac{\mathrm{o}}{\mathrm{o}} \mathrm{U}_{3} \mathrm{O}_{8}\right) \\
\end{array}$ & $\begin{array}{r}\text { Yellowcake } \\
\text { Production } \\
\text { (tons/year) } \\
\end{array}$ & $\begin{array}{c}\text { Workers in } \\
\text { Drying and } \\
\text { Packaging Area } \\
\end{array}$ & $\begin{array}{c}\text { Total } \\
\text { Workers } \\
\end{array}$ \\
\hline 1 & Confidential & Confidential & $0^{(\mathrm{a})}$ & 15 \\
\hline 2 & Confidential & Confidential & $0^{(a)}$ & 30 \\
\hline 3 & 0.16 & 100 & 3 & 70 \\
\hline 4 & 0.129 & 90 & 3 & 41 \\
\hline 5 & 0.17 & 500 & 12 & 153 \\
\hline 6 & 0.15 & 450 & 19 & 133 \\
\hline 7 & 0.10 & $75,000^{(b)}$ & $0^{(a)}$ & 34 \\
\hline 8 & 0.037 & 36 & $0^{(a)}$ & 32 \\
\hline Total & & & 37 & 508 \\
\hline
\end{tabular}

(a) No product drying.

(b) Weight as slurry. 
Each facility conducts external gamma radiation monitoring throughout the plant using portable survey instruments and fixed-location TLDs. Measurements are evaluated at monthly or quarterly intervals. A urinalysis program for all workers is in place at 62 percent of the solution mining facilities. The remaining sites conduct urinalysis measurements only on yellowcake precipitation or packaging and maintenance workers. The sampling frequency is highly variable. One facility conducts weekly urine sampling, while others obtain biweekly, monthly, quarterly, or annual samples. Average results are reported to be less than $5 \mu \mathrm{g} / \mathrm{l}$.

Routine chest counting is not performed at any of the facilities. Each facility monitors personnel exposures to external gamma radiation. One facility reported use of film dosimeters, while the remainder use TLDs. Use of respirators is mandatory in the yellowcake drying and packaging area at each facility that produces a dry product.

\subsection{URANIUM RECOVERY OPERATIONS}

Employment and production information on four responding uranium recovery operations is presented in Table 10 .

Of the two facilities that provided process information, one utilizes a $400^{\circ}$ to $500^{\circ} \mathrm{C}$ yellowcake drying process, and the other ships its product as a yellowcake slurry.

TABLE 10. Uranium Recovery Operations Production and Employment Data

\begin{tabular}{|c|c|c|c|}
\hline Operation & $\begin{array}{l}\text { Yellowcake } \\
\text { Production } \\
\text { (tons/year) }\end{array}$ & $\begin{array}{c}\text { Product Drying } \\
\text { and Packaging } \\
\text { Area Workers } \\
\end{array}$ & $\begin{array}{c}\text { Total } \\
\text { Workers }\end{array}$ \\
\hline 1 & 14 & $0^{(a)}$ & 58 \\
\hline 2 & 200 & 6 & 55 \\
\hline 3 & (b) & (b) & (b) \\
\hline 4 & Confidential & Confidential & Confidential \\
\hline
\end{tabular}

(a) No product drying.

(b) Shutdown due to litigation. 
All four operations sample continuously for airborne uranium during product drying and packaging operations. However, only one of the facilities conducts a radon daughter monitoring program.

All workers are involved in a biweekly urinalysis program. Three facilities reported an average urinalysis result less than $5 \mathrm{\mu g}$ uranium per liter urine, and one reported an average of 9 to $12 \mu \mathrm{g} / \ell$.

Chest counting is routinely performed at two operations, infrequently at a third, and only following suspected overexposures at the fourth.

Personnel external gamma dosimeters are worn by employees at each uranium recovery facility. Three employ TLD badges; the fourth employs film badges. Dosimeters are processed monthly or quarterly.

Respirators are required during all drying and packaging operations.

\subsection{HEAP-LEACHING PROCESSES}

One of the three current heap-leaching operations completed the questionnaire. The operation has only one worker in yellowcake drying and packaging area during operating hours. Six different workers are rotated in and out of this position.

The yellowcake product is dried at between $300^{\circ}$ and $400^{\circ} \mathrm{C}$. Daily grab samples for airborne uranium are taken in the drying and packaging area. Quarterly radon daughter measurements are taken inside the mill building. External gamma radiation measurements are taken monthly using portable survey instruments. TLDs placed at fixed locations throughout the mill are also read at quarterly intervals.

Urinalysis is conducted on all mill workers. Workers in the product drying area require monthly urinalysis, and all other workers receive quarterly urinalysis. Results average $<5 \mu \mathrm{g} / \ell$. Lung counting is routinely performed. However, personnel external gamma dosimeters are not worn. Respirator usage is mandatory during product drying and packaging operations and during maintenance activities in this area. 


\subsection{REFERENCES}

American National Standards Institute. 1966. Practice for Occupational Radiation Exposure Records Systems. ANSI N13.6.

American- National Standards Institute. 1969. Practices for Respiratory Protection. ANSI Z88.2.

Atomic Industrial Forum. 1977. Workshop on Methods for Measuring Radiation In and Around Uranium Mills. Program Report Vol. 3, Number 9, AIF, Washington, D.C.

Cooke, N., and F. B. Holt. 1974. "The Solubility of Some Uranium Compounds in Simulated Lung Fluid." Health Phys. 27:69-77.

Dennis, N. A., H. M. Baluer and J. E. Kent. 1982. "Dissolution Fractions and Half-Times of Single Source Yellowcake in Simulated Lung Fluids." Health Phys. 42:469-477.

Fisher, D. R., P. O. Jackson, G. G. Brodaczynski and R. I. Scherpelz. 1982. Measurements of ${ }^{234} \mathrm{U},{ }^{238} \mathrm{U}$, and ${ }^{230} \mathrm{Th}$ in Excreta of Uranium Mill Crushermen. NUREG/CR-2503, Pacific Northwest Laboratory, Richland, Washington.

Hanford Environmental Health Foundation and Pacific Northwest Laboratory, Kichland, Washington. 1981. Occupational Exposures to Uranium: Processes, Hazards and Regulations. PNL-3341, USUR-01.

Harley, J. H. 1972. HASL Procedure Manual. HASL-300. Health and Safety Laboratory.

Kalkwarf, D. R. 1979. Solubility Classification of Airborne Products From Uranium Ores and Tailings Piles. NUREG/CR-0530, Pacific Northwest Laboratory, Richland, Washington.

U.S. Atomic Energy Commission (AEC). 1973. Acceptable Concepts, Models, Equations, and Assumptions for a Bioassay Program. Regulatory Guide 8.9, Washington, D.C.

U.S. Atomic Energy Commission (AEC). 1974. Applications of Bioassay for Uranium. Regulatory Guide 8.11, Washington, D.C.

U.S. Atomic Energy Commission (AEC). 1975. Applications of Bioassay for Uranium. WASH-1251.

U.S. Code of Federal Regulations, Title 10, Part 20, "Standards for Protection Against Radiation" (1980). 
U.S. Code of Federal Regulations, Title 10, Part 40, "Licensing of Source Material" (1980).

U.S. Code of Federal Regulations, Title 29, Part 1910.134, "Occupational Safety and Health Administration Regulations".

U.S. Department of Energy (DOE). 1980. Statistical Data of the Uranium Industry. GJO-100 (80), DOE Grand Junction Office, Grand Junction, Colorado.

U.S. Nuclear Regulatory Commission (NRC). 1976a. Acceptable Programs for Respiratory Protection. Regulatory Guide 8.15, Washington, D.C.

U.S. Nuclear Regulatory Commission (NRC). 1976b. Manual of Respiratory Protection Against Airborne Radioactive Materials. NUREG-0041.

U.S. Nuclear Regulatory Commission (NRC). 1977. Standard Format and Content of License Applications for Uranium Mills. Regulatory Guide 3.5 (Revision 1), Washington, D.C.

U.S. Nuclear Regulatory Commission (NRC). 1978. Bioassay at Uranium Mills. Regulatory Guide 8.22, Washington, D.C.

U.S. Nuclear Regulatory Commission (NRC). 1980. Final Generic Environmental Impact Statement on Uranium Milling. NUREG-0706. Washington, D.C.

Wilde, R. M. 1975. "Occupational Health Experience With Uranium in Ore Processing Mills." In Conference on Occupational Health Experience With Uranium, ERDA-93, U.S. Government Printing Office, Washington, D.C. 


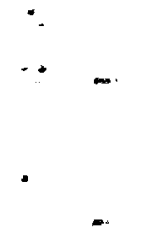

$\rightarrow$
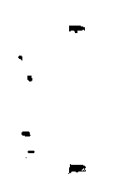


\section{DISTRIBUTION}

No. of

Copies

No. of

OFFSITE

Copies

27 DOE Technical Information Center

P. W. Durbin

Lawrence Berkeley Laboratory

1 Cylotron Road

Room 101, Building 74B

R. E. Alexander

Occupational Radiation Protection Branch

Nuclear Regulatory Research

U.S. Nuclear Regulatory Commission

Washington, DC 20555

R. Beckman

Mine Safety and Health

Administration

P.O. Box 25367

DFC

Denver, CO 80225

Berkeley, CA 94720

R. D. Evans

4621 Crystal Lane

Scottsdale, AZ 85253

E. E. Kennedy

Homestake Mining

P.O. Box 98

Grants, NM 87020

C. W. Mays

Radiobiology Laboratory, Building 522

R. S. Brief

Exxon Corporation

P.O. Box 235

East Millstone, NJ 08873

J. Cleveland

Kerr-McGee Nuclear Corp.

P.O. Box 218

Grants, NM 87020

E. Conti

Division of Health, Siting and Waste Management

U.S. Nuclear Regulatory Commission

Washington, DC 20555

R. E. Cunningham

Division of Fuel Cycle and Material Safety

Nuclear Material Safety and Safeguards

U.S. Nuclear Regulatory

Commission

Washington, DC 20555

University of Utah

Salt Lake City, UT 84112

H. M. Parker

2030 Harris

Richland, WA 99352

J. W. Poston

School of Nuclear Engineering Georgia Institute of Technology

Atlanta, GA 30332

H. B. Rhodes

Union Carbide Corporation

P.O. Box 1029

Grand Junction, CO 81502

C. E. Roessler

Environmental Engineering Sciences

University of Florida

Gainesville, FL 32611 
No. of

Copies

A. T. Sabo

Westinghouse Electric

Nuclear Safety Division

P.O. Box 355

Pittsburgh, PA 15230

W. J. Shelley

Kerr-McGee Nuclear Corp.

McGee Tower

Oklahoma City, OH 73125

J. N. Stannard

17441 Plaza Animado, No. 132

San Diego, CA 92128

F. Swanberg, Jr.

Siting and Environment

Nuclear Regulatory Research

U.S. Nuclear Regulatory

Commission

Washington, DC 20555

L. W. Swent

Vice President

Environmental Affairs and

Occupational Health and Safety

Homestake Mining Company

650 California Street

San Francisco, CA 94108

W. W. Weyzen

3412 Hillview Ave.

P.O. Box 10412

Palo Alto, CA 94303

R. W. Wheeler

NIOSH

944 Chestnut Ridge Road

Morgantown, WV 26505

G. E. Wilkinson

Gardinier, Inc.

P.O. Box 3269

Tampa, FL 33601
No. of

Copies

FOREIGN

C. Pomroy

Radiation Protection Bureau

Health and Welfare Canada

B rookfield Road

Ottawa, Ontario

CANADA

\section{ONSITE}

2 DOE Richland Operations Office

H. E. Ransom/P. K. Clark

K. W. Bracken

48 Hanford Environmental Health

Foundation

B. D. Breitenstein (5)

S. E. Dietert

R. H. Moore (40)

G. R. Petersen

M. J. Swint

49 Pacific Northwest Laboratory

R. W. Baalman

F. T. Cross

T. H. Essig

L. G. Faust

D. R. Fisher (20)

M. G. Foley

W. A. Glass

D. E. Hadlock

K. R. Heid

G. R. Hoenes (3)

R. L. Kathren

S. Marks

R. W. Perkins

H. B. Spitz

G. A. Stoetzel (5)

L. A. Rathbun

C. M. Unruh

Technical Information (5)

Publishing Coordination (2) 